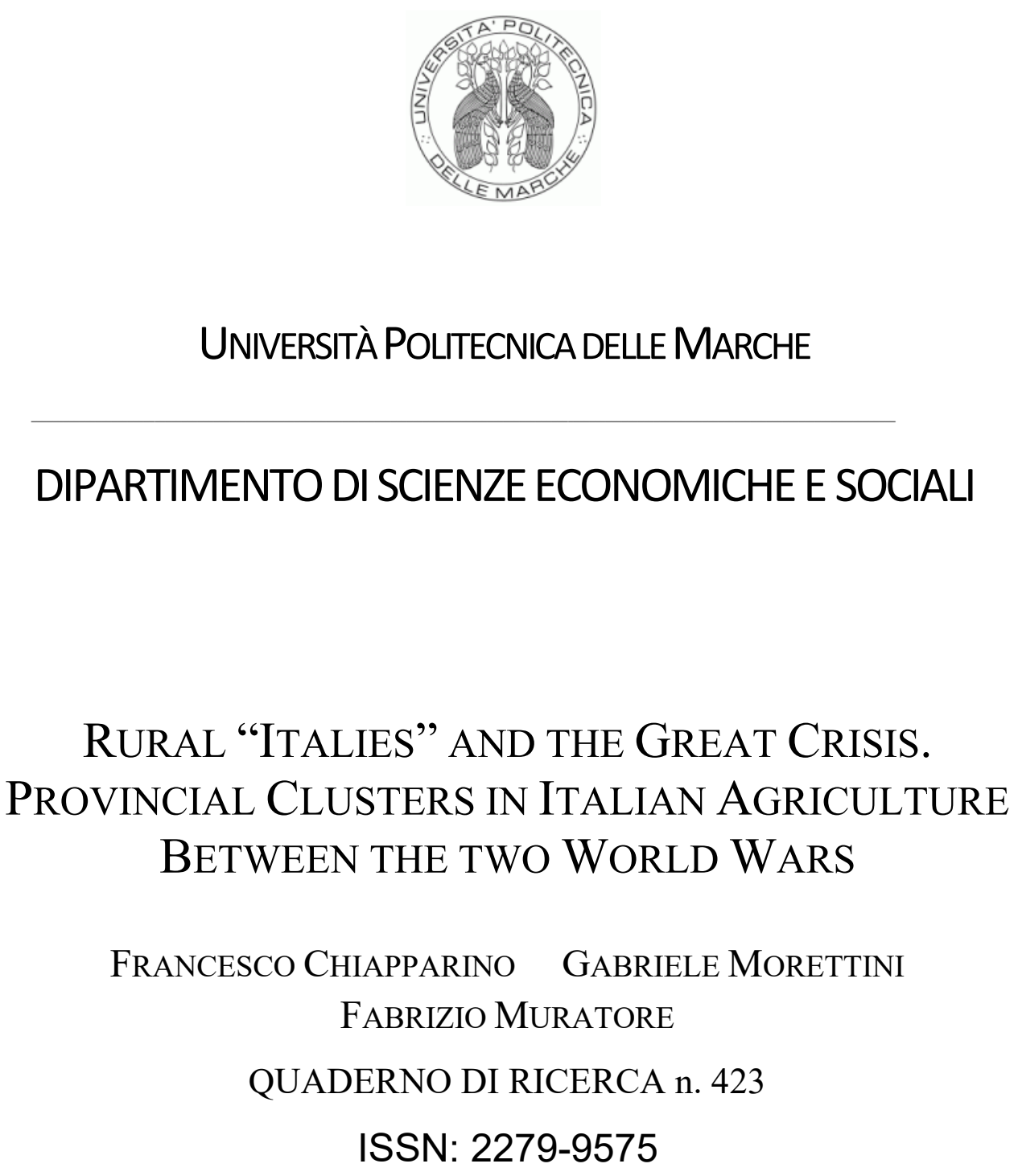

ISSN: 2279-9575

July 2017 
Comitato scientifico

Marco Gallegati

Stefano Staffolani

Alessandro Sterlacchini

Alberto Zazzaro

Collana curata da:

Massimo Tamberi 


\section{Rural "Italies" and the Great Crisis. Provincial clusters in Italian agriculture between the two World Wars}

Francesco Chiapparino, Gabriele Morettini, Fabrizio Muratore (Università Politecnica delle Marche, Ancona - Italy)

This contribution aims to investigate the dynamics of Italian agriculture during the crisis of the Thirties, as well as related issues such as the role of some policies deployed to contain the recession and their consequences. To that end, the paper adopts a particular viewpoint based on the belief that Italy presents a large variety of rural environments, the result of its geography and history, and is characterized by different cultivations, features, conduction systems, productivity levels, and market orientations - in other words, diverse modes of production. Partitioning these "rural Italies" allows us to analyze their trends and prevents them from being bundled together in such a way as to compensate and sometimes even nullify each other. Moreover, the Fascist regime introduced active incentive and protectionist (even autarkic) policies to contrast the recession. Split into the plurality of its agrarian contexts, therefore, the country becomes a sort of kaleidoscope, through which it is possible to observe both the relatively wide set of effective changes brought about by the depression and the diverse impact of national policies.

Keywords: Crisis, Italy, (Agrarian) Clusters, Fascism, Yields

\section{Crisis and agriculture}

At international level, agriculture held a key position in the first investigations on the interwar crisis. Economists like Ohlin (1931) or Timoshenko (1933) based their whole analyses of the 1929 depression on the downturn in agricultural prices and the collapse in the global trade of rural commodities. As far back as the Thirties, however, and increasingly so in the following decades, the relevance of the primary sector declined in favor of other explanations such as financial speculation (Galbraith 1961, Minsky 1982), monetary dynamics (Friedman, Schwartz 1963: 299ff., Eichengreen 1992), the monopolistic tendencies of large-scale industries (Berle, Means 1968, Sweezy 1968), demographic stagnation and the connected investment cycles (Hansen 1939). At the beginning of the $21^{\text {st }}$ century agriculture was even explicitly classified as "not guilty" of causing the recession, at least as regards the subjective non-responsibility of the US farmers' investment behavior for the onset of the depression (Federico 2005).

Following another traditional approach to the issue (Kindleberger 1973: 66-88, Aldcroft 1977: 223238), more recent analyses have re-evaluated the decisive role that the primary sector might have had in contributing to, even if not in triggering, the extent and the prolonged duration of the 1930s recession and therefore is one of the main features of the comparison which is often made 
with the current crisis (Delli Gatti et al. 2012). This latter perspective emphasizes the impact of the severe drop in agricultural prices, and consequently in the related incomes, on aggregate demand, for an economy in which agriculture still employed a large part of the workforce.

On the contrary, this work does not go as far as to investigate issues which directly concern incomes and the effects of the crisis on aggregate demand. These aspects can only be dealt with by analyzing data on rural prices and their local structure at the time, which at present are only very partially available for Italy. Therefore, the aim here is limited to the previous question of the dynamics of the primary sector during the recession of the Thirties in terms of real (non-monetary) production and physical productivity. In other words, investigating whether, and to what extent, agriculture experienced a depression is a first step towards understanding if the rural crisis affected the overall economic recession.

The Italian case, however, also raises further questions. The most obvious is the relatively small size of the country, and therefore its limited influence not only on world market dynamics but, even more so, on the onset of international recession. Nonetheless Italy presents some interesting peculiarities. As will be seen, the variety of its agriculture, with its diverse vocations, market orientations and degrees of protection, makes the Italian peninsula an exemplary case, which reflects (and can be useful for a comparison with) significant international trends. Even from a geographical point of view "Italy along the almost 1200 kilometers from the Alps to the African seas displays a variety of physical features as we find in other earth areas across a meridian arch of 3 or 4 thousand kilometers" (Gambi 2008: 207).

Moreover, it should be highlighted how Italy, with $50-60 \%$ of the whole workforce employed in the primary sector and the latter representing a 30-40\% share of the global added value (Baffigi 2013: 231, Broadberry et al. 2013: 278), was still largely an agrarian country between the two wars, and was actually destined to remain only partially and unevenly industrialized up to the "economic miracle" of the late 1950s-1960s. All these factors make the country a good testing ground for analyzing the relationship between agriculture and the crisis, both for the specific dynamics of the interwar period and in general as an example of a developing economy.

A final issue concerns the markedly protectionist orientation of Italian agricultural policy, which complicates the analysis of the impact of the drop in prices, similarly to what happened at that time in several other European countries, like France and Spain. Although it always remained a net importer of subsistence products, in particular wheat, starting from the Great Depression of the late 19th century Italy adopted significant duties on cereals and other agricultural commodities, such as rice and sugar, which were essentially aimed at supporting the income of the landowners (Bonelli 1978, Fenoaltea 2006: 172-187). This type of orientation was renewed and even reinforced by the Fascist regime, which as from 1925, before the crisis, launched the Battaglia del grano with the explicit purpose - although never completely achieved - to reach self-subsistence in food production. This target, all the more desirable after the US block on immigration, oriented the regime to increasing protectionism, which became autarky after the aggression toward Ethiopia and the League of Nations sanctions. Together with land reclamation, which had a more localized impact (Bevilacqua, Rossi Doria 1984, Stampacchia 2000), the Battaglia del grano represented the main and most propagandized agrarian policy of the Fascist regime. Protectionism 
was, after all, a way to subsidize farmers (owners) at the expense of domestic consumers rather than through the State budget, which was constrained after 1926-1927 by the reintroduction of the Gold Standard ${ }^{1}$. On the other hand, however, this policy could not prevent the drop in prices of commodities sold on the international market, despite government efforts to mitigate these losses through bilateral export agreements and duty drawbacks. This set of measures, protections and incentives, combined with different endowments, forms of conduction and market orientations in the rural areas of the country, produced a fairly wide range of performances.

Notwithstanding several detailed reconstructions of the recession in single contexts, the overall picture so far is inevitably general and mostly limited to signaling contrasting trends. Extended wheat production even on unsuitable land, the difficulties of mountain territories and some specialized crops, and a better reaction to the crisis in the Po Valley than elsewhere are the most remarkable pieces of evidence (Zamagni 1993: 329, Ciocca 2007: 209-12). Even detailed analyses of the Fascist agricultural policies such as those by Cadeddu, Lepre, Socrate (1975), end especially Fano (1975) and Cohen (1976 and 1979), which are very similar to the approach and the outcomes of this work, suffer from the lack of an appropriate territorial disaggregation. In this way, the impact of the depression appears to be limited, especially in comparison with the big transformation of the 1950s-1960s, when the "economic miracle" was accompanied by the rural exodus and the disruption of agricultural society. On the contrary, a key hypothesis of this work is that, from another perspective, many of these changes were already in the making during the interwar crisis - and sometimes were even started by the recession.

\section{Rural Italies}

"... An agricultural Italy however does not exist yet; on the contrary there are several agricultural Italies which are quite distinct from each other; so great and manifold is the influence of the differences in climate that can be found between the Alps and Lilybaeum, the historical, moral, administrative, and legislative traditions, which are so diverse from region to region; the invincible slow pace of agricultural changes; the disparity of treatment between landowners with respect to the public burdens in the absence of cadastral unification; the numerous and ramified means of communication which are needed for agriculture, compared with the manufacturing industry, with each and every piece of cultivated land representing an agricultural workplace".

This long quotation comes from the first important national agrarian enquiry, twenty years after the proclamation of the Kingdom of Italy, and shows how the idea of the variety of Italian rural geography is far from being new (Jacini 1881: 1.4). The enthusiasm for political unification overshadowed this awareness, that was once again brought incontrovertibly to the attention of the country and its ruling classes by the above mentioned Inchiesta Jacini - not without the nuance of bitterness deriving from the backwardness of several rural contexts and the consequent obstacles to social and economic unification.

\footnotetext{
${ }^{1}$ Deficit spending policies were nevertheless pursued during the crisis for saving banks and heavy industry, albeit moderately and taking care to maintain a control over the amount of money in circulation. See Ciocca 2007: 206-209.
} 
The perception of the set of different geographical, social, historical and cultural conditions characterizing the several rural contexts of the peninsula became fairly common in the social and political dialectic of the new Kingdom. At the turn of the century, in particular, this idea fueled the great debate around the "Southern question", raised by the inquiry on Sicily carried out by Franchetti and Sonnino (1876) and the articles written by Pasquale Villani (1878). This issue has engaged major Italian intellectuals throughout the whole of the twentieth century and even up to the present day (Bevilacqua 2016: 15-28, Cassese 2016). The emphasis on the North-South divide was fully justified by the dramatic inequalities emerging in the country and the political urgency of their social consequences. It had the effect, however, of firstly extending the analyses to a much wider set of issues, involving tax and trade policies (Nitti 1900, Fortunato 1911), class conflicts and delays in capitalist development (Gramsci 1949: 59-157, Sereni 1968), industrialization processes (Cafagna 1990: 181-220; Fenoaltea 2006: 216-271), the general ruling and investment choices taken after the unification (Romeo 1959), cultural, civic and even moral attitudes in different parts of the peninsula (Banfield 1958, Putnam 1993). Above all, however, what is of interest here is the central role of the Mezzogiorno problem which led to polarization and neglected the concept of variety in Italian agriculture, tending to reduce the latter issue to the dualistic development of the country - which was perhaps even more crucial per se.

Together with the debate on the North-South divide, however, the question of Italian rural plurality continued to offer food for thought throughout the 20th century, albeit in a less prominent position. For instance, awareness of the deep differences in the country permeated most agronomic knowledge. There is no handbook from the first half of 1900 that does not present the diverse cases of farm accountancy, crop management or estimated returns for the different areas of the country, their uses and forms of conduction (Niccoli 1898 and 1927, Tassinari 1941). Similarly, the variety of yield and profitability in Italian agriculture clearly emerged from some attempts to estimate the total production of the primary sector at regional and provincial level (Zattini 1924).

It is however only after the Second World War that the debate on Italian rural systems makes significant headway. A basic contribution in this sense was made by Emilio Sereni (1961), with his long-lasting reconstruction of Italian rural landscapes, from the time of Greek colonization up to the last big land reclamations of the post-war age. His analysis not only identifies the main agricultural systems in the peninsula, but also outlines their historical changes from pre-Roman times onwards. Consistently with Sereni's Marxist position, this evolution is described in terms of interaction between natural environments, rural techniques and social relationships. Such a reconstruction is based on a solid set of juridical, statistical, and archaeological sources, which nonetheless also rely on innovative methodologies, such as the widespread use of the history of painting to describe and analyze rural environments. The result is a pioneering synthesis that focuses on the landscape as a new field of interdisciplinary research (Agnoletti 2011) and gives historical consistency to the idea of the variety of Italian rural systems.

Finally, a further decisive stage in the debate on rural "Italies" is represented by Lucio Gambi's study (1972) which defines, using the 19th century Humboldt terminology, the "environmental frameworks" of the peninsula and their "historical values". Gambi identifies four macro-areas (Alps, Po valley - divisible in dry and irrigated - Apennines and sub-tropical coastal plans), then 
follows their evolution and partitions in the long term through the interaction with human activities. In this way, he provides general guidelines for analyzing the spatial organization of the different agricultural contexts in Italy and their subsequent evolution through industrialization.

Along these lines, an awareness of Italian agricultural pluralism pervaded the proliferation of local studies when, in the 1970s-1980s, Italian historiography had moved away from national interpretations and adopted the new territorial perspective opened up by the institutional changes of the period (Nenci 1997: 121ff.). Such an approach is largely reflected in the important collective works that, at the turn of the century, reviewed that fruitful season of research (Bevilacqua 1989-1991; De Bernardi, D'Attorre 1996, Storia d'Italia 1997-2002). In some ways, rather than denying the North-South divide, these studies embraced the issue. The assumption that the Mezzogiorno did not have the physical (geography, climate, soils, etc.) conditions to deal with the forage revolution of the 18-19th century and the later introduction of machines and fertilizers (Corona, Masullo 1989), implies (and derives directly from) the recognition of the diverse ecosystems - respectively continental and Mediterranean - that represent the framework of the several rural economies of the peninsula.

On the other hand, quantitative analyses, detailed territorially and aimed at identifying these rural economies, concern almost exclusively the second half of the $20^{\text {th }}$ century. Generally, they are focused on the regional scale (Pierani, Rizzi, 2006; Esposti 2014) and addressed to spotting the driving forces of the big changes in postwar Italian agriculture. Sub-regional and local studies ranging from agrarian economics to geography, are mainly oriented to the recognition of homogeneous agricultural systems for rural policy interventions (Coppola et al., 1991). The few studies on the prewar period prevalently use a deductive approach. The division of the country into homogeneous areas traces "with natural will the dividing line between realities that shade one into another by degrees" (Inea, 1954: 444). Partitioning at the beginning of the 1950s - and therefore reasonably not too dissimilar from the situation in previous decades - is outlined by assembling at discretion the agrarian regions (mountain, hill, plain) of each province. The result is not unlike that of the present work, but it is based on a totally specular methodology, being deductive rather than inductive. Orlando also proposes a partitioning of Italian agriculture through discretionary criteria, set ex ante. The four areas identified (the Apennines mountains and hills, Alps mountains, internal hills and plains of the Centre and the South, the Po Valley hills and plains) are the result of a classification that he himself defines as defective but obliged by the lack of more detailed data (Orlando, 1974: 551). Unlike demographic studies, which benefit from the indepth consideration of census estimates, statistics on agricultural production are bound to the provincial scale by the scarcity of information prior to 1951 (except for 1929 Cadastre). More detailed investigations are therefore limited only to 1929 and oriented mostly for descriptive and classification purposes. Giusti's meticulous analysis (1943) starts with the agrarian zones, supplemented with information at municipal scale. The resulting 178 homogeneous areas are then examined in the light of many environmental, social and demographic features. The accuracy of detail, however, goes to the detriment of synthesis: the proposed classification is a careful snapshot, albeit hardly functional to understanding the real situation of Italian agriculture, which requires spatial clusters and temporal dynamics. Similar reserves may be expressed on the recent contribution by Martinelli (2014), whose detailed reconstruction of Italian agriculture in 1929 is 
functional to a cross-sectional regression between the 793 Italian agrarian regions. The focus on agrarian region necessarily implies neglecting the temporal dimension, because these data are available only for 1929. "It is very difficult for such a complicated description to serve purposes other than those for which it was created" (Giusti, 1943: 84), that is to provide a precise picture of the national primary sector at a specific moment in time.

Cadastral data allow us to classify agriculture and identify local homogeneous areas, but these must then be brought back to the provincial scale, which is the most detailed territorial level for building a reliable time series.

Finally, other relatively recent quantitative studies also concern agriculture at a national or regional level, without further investigating the local scope (Felice 2007, Daniele, Malanima 2011). The originality of the present work is therefore the application of an inductive method and quantitative analyses for a period which is almost always only investigated on a documentary and qualitative basis, or by focusing the national (or at the most the regional) aggregate, or a specific year, neglecting temporal dynamics.

\section{Methodology: Principal component analysis (Pca) and clusterization.}

If on the one hand the proliferation of local investigations provided enriched insight into Italian rural history, on the other these studies were only rarely arranged in a coherent national framework that allows us to map the mosaic of the different agrarian environments in the country, locate their boundaries and compare their relative performance (Cohen, Federico 2001: 41).

The present work is specifically intended to contribute to the latter, by identifying the Italian rural contexts and their changes during the recession of the Thirties. Thus, it uses the earliest reliable data available for this purpose, provided by the 1929 Catasto agrario. This cadastre was the result of long-term efforts to improve national agricultural statistics, after the foundation of the International Institute of Agriculture (later known as Fao) in Rome in 1905 had brought to light the serious mismatching of the previous investigations (Soresina 2001). The work of revision was slowed down by the First World War and was re-launched when the Italian National Institute of Statistics (Istat) was set up in 1926. The land register was completed on the eve of the crisis and was soon integrated in 1930 by the Livestock Census. Emphatically defined as "the book of Italian agriculture", starting from 1936 it was also the basis for the updating of the periodic series for rural production (Bollettino), which allowed the effects of the recession on Italian agriculture to be analyzed.

The first step in the current study, however, consists in the identification of the diverse rural environments throughout the peninsula in 1929. To that end, two procedures were adopted: first Pca, and then clusterization.

The Pca considered data from the 279 Agrarian regions, which bring together the Agrarian zones (i.e. 793 groups of single municipalities with similar natural and farming conditions) for each of the 92 Italian provinces recognized at that time (including those annexed to Yugoslavia in 1945) on the basis of the common altitude location (mountain, hill or plain). The panel data include all the most 
important information provided by the Catasto, such as agricultural and forestry area (Afa), uncultivated land and woods, cultivated areas, production and yields of the main crops, land conduction forms (see Tab.1). In this sense, the choice of variables is in line with the literature, that even before the war had stressed the advisability of relying on natural, economic and social criteria to analyze rural environments (Giusti, 1943: 83). After a preliminary descriptive analysis of the data Pca allowed the original 51 selected variables to be reduced to ten recurrent associations (components), summarizing the panel without altering its basic information. Our criteria identify a sufficiently high percentage of total variance: in particular, we extract a number of components with eigenvalues higher than 1 and which are able to explain at least $70 \%$ of the total variance (Jolliffe 2002: 111ff). The factor loadings matrix (Tab.2) shows that some components are clearly associated to special productions, whereas others, which are correlated to many elements, identify a combination of crops, yields or conduction forms, rather than a peculiar farm specialization.

The first three components ${ }^{2}$ encompass most of the variability (around $46 \%$ ) and summarize the main types of Italian agriculture. Component $A$ is the typical intensive agriculture, characterized by the association of a few productions (wheat, maize, cattle and meadows), with high yields, large use of laborers, machines and fertilizers. Component B is the extensive agriculture, typical of areas with no local specializations (for instance citrus fruits) but nonetheless characterized by woody crops (especially olive trees and almonds) associated with durum wheat, broad beans, sheep, goats and day laborers. Component $\mathrm{C}$ describes mountain agriculture, characterized by chestnut trees, pastures, woods, uncultivated lands and the presence of small owners.

Component $D$ refers to areas with woody plants and negative loadings of arable land and pastures. Component $\mathrm{E}$ is made up of multiple variables, that suggest a dual interpretation based, on the one hand, on sharecropping (whose loadings assume a positive, significant value only in this case) and, on the other, on woody crops such as vines and olive trees (and, partially, tobacco). The comparison with component $D$ underlines the fact that component $E$ identifies a multi-crop agriculture widespread in the hilly areas of the Apennines. Component $F$ is related to the industrial farming of beet sugar and hemp, together with significant loadings of commercial fruit crops like peaches. Component $\mathrm{G}$ refers to citrus fruit specialization, a sector in which Italy had a leading position in the Twenties, especially for lemons, but also for oranges, bergamots, citron, etc. (Lupo 1990). Component $H$ shows only a moderate correlation with durum wheat, broad beans and almonds, identifying the association of alternated extensive cereals with intensive orchards, whereas component J presents a clear link only with potato cultivations, spread over many territories, especially on the rugged terrain. It indicates unspecialized farming with low yields, which is typical of disadvantaged areas. Finally, component $K$ constitutes the profile of the intensive rice farming of the irrigated plain.

The second investigation consisted in a cluster analysis of the new components, in order to group together homogeneous provinces. The agrarian partitions of the peninsula were approximated at provincial level, i.e. territorial units smaller than Regions. The latter are commonly used in statistical reconstructions (Daniele, Malanima 2011, Svimez 2011), but represent very

\footnotetext{
${ }^{2}$ The components (or factors), usually indicated by numbers, are here denominated by letters to avoid confusion with the following cluster analysis.
} 
heterogeneous districts (both within and between each other) which before 1970 were purely statistical. Provinces do not identify homogeneous areas either, but they obviously represent a more detailed approximation and provide, as anticipated, reliable and comparable longitudinal data, in contrast with smaller territorial bodies, such as municipalities and agrarian zones.

Clustering techniques are based on measures of similarity between elements, which in many approaches are conceived in terms of distance in a multidimensional space. We use the Euclidean distance and the Ward's hierarchical clustering method. The results are usually presented in a dendrogram (Fig.1) from which we identify 18 clusters, summarily described below and more thoroughly in the Appendix. Indeed, they represent the geography of Italian agriculture in 1929, as emerges empirically from the data (physical, productive and social) in the land register.

These clusters, which will be described later, can be further divided into three types: the basic partitions of the country, their variants (often marginal), and those with strong and peculiar cultivation characteristics, which are often but not always specialized. The first typology includes twenty provinces of the Alpine Arc (Cluster 1)- the plain portions of which however share features with the Po Valley - the wide hilly area of Central Italy characterized largely by mixed crops and sharecropping (Cluster 9), and the extensive agriculture of the Southern Apennines (Cluster 10). Clusters 11 and 18 can be considered variables of the latter, respectively with a prevalence of arable land, often associated to large extensions of plain as found in the provinces of Rome and Foggia, and with a peculiar scarcity of resources in the case of Sardinia. Analogously, Liguria and High Tuscany (Cluster 4) and the provinces of the Messina Strait (Cluster 15) could be associated to the mountain agriculture of the Alpine Arc for their lack of arable land. Variants are represented here by the Mediterranean environment, and its specialized cultivations, respectively olives and flowers in the Northern Apennines and citrus fruits in the South. A final set regards the specialized clusters, or at least those with marked productive features. In the North, there are two types: the first encompasses three clusters of the Po Valley that share the same basic intensive agriculture based on alternating wheat and maize, a good availability of cattle and a particularly strong network of urban markets. These clusters represent Low Lombardy, rich in cereals, permanent meadows and livestock (Cluster 5), its Piedmont variant featuring rice (Cluster 3 ) and the Veneto Plain (Cluster 6 ), characterized by a larger incidence of peasant properties but also oriented to industrial or fruit cultivations. The discrimination of these three variants can be considered a successful result of the analysis, giving empirical evidence for both the classical assumption about the partitioning of the Po Valley agriculture along the Ticino and Mincio Rivers (see for instance Crainz 1992: 37, 56) and the historical heritage of the pre-Unification organization of the Piedmont, Lombardy and Veneto territories. Further Northern Clusters include Asti, with its peculiar hilly specialization in vines (Cluster 2), as well as those of the Po Delta (Cluster 7 and 8), characterized by wide reclamation plains, high crop versatility and, especially in the province of Ferrara, a strong incidence of large capitalistic estates. Finally, the most dynamic nucleus of Southern agriculture should be mentioned: the Sicilian woody cultivation of vines and citrus fruits (Cluster 17), and its variant in the central part of the island (Cluster 16), where large cereal estates are juxtaposed to particularly widespread almond orchards; the section of Apulia specialized in vines, olive and almond trees (Cluster 13), with the adjacent province of Lecce, which was also 
strongly oriented toward tobacco cultivations (Cluster 14); and the Naples area (Cluster 12), the richest (at least per hectare yields, Zattini 1924) and most differentiated Italian agricultural province, with all sorts of arable, woody and industrial cultivations.

\section{Agricultural dynamics, the crisis and Fascist policy}

The geography of Italian agriculture resulting from multivariate analysis can be the basis for examining the agrarian changes that occurred in the interwar period. As already mentioned, the Great Crisis and the Fascist regime policies make the Thirties a turning point, fraught with implications both for the evolution of Italian agriculture and as a more general case study.

The performance of the different clusters will initially be evaluated with regard to the national policy of protection and incentives for wheat production, and afterwards considering their individual productive vocations. This sequence allows us to present first the common ground where cluster performance is comparable and subsequently their peculiar specializations.

It must be considered that agricultural statistics were not updated on the basis of the Catasto prior to the mid-Thirties. Therefore, the comparison will be carried out here for the average of the years 1923-1929 (cadastral data ${ }^{3}$ ) and 1936-1938 (Istat 1940). This includes the years 1925 to 1928, during which the main changes started: the Battaglia del grano as well as the downturn in international agricultural prices and the return of the lira in the Gold Exchange Standard (1927), which entails a significant loss of competitiveness for Italian exports (Patnaik 2003). In any case, the period 1923-1938 allows us to capture the densest phase of the transformations related to the crisis which hit Italy in 1930, and the subsequent autarkic policies. 1936 was particularly bad for agriculture, not only in Italy; nonetheless, bad years exist and the choice to include them makes the comparison more realistic. If one considers only 1937 and 1938, yield performances are better but trends are confirmed.

The Battaglia del grano fostered significant improvements especially in seed selection and the use of machinery and fertilizers (Rossini, Vanzetti 1986: 640-53). In parallel, by 1931 the duty on wheat had been pushed up to 19 gold lire/hundredweight, i.e. from $70 \%$ to over $100 \%$ of the value depending on price fluctuations (Tattara 1978). In 1936, together with autarky, compulsory consignments were introduced, together with State control of the remaining imports.

Wheat represented almost all the increase in cultivated area, passing respectively from 23.3 to 24.4\% and from 52.4 to $53.5 \%$ of an Afa which remained almost the same between 1929 and 1938. Wheat expanded in new terrains, at the expense of other arable crops and fallow land. If woods and wood cultivations remained unchanged, the weight of pastures dropped from 15.9 to $15.3 \%$ of the Afa. This reduction mainly affected the South, where a tax on goats, introduced in 1927 to encourage reforestation, added to the difficulties of sheep farming. The agricultural policy thus promoted a rapid conversion of some marginal land from pasture to grain cultivation, sacrificing resources for animal feed (Tino 2016). At national level, all this implied a $7 \%$ increase in

\footnotetext{
${ }^{3}$ For each product, the Land register records yields and cultivated area in 1929 and the yield average of the previous six years, from 1923 to 1928 , with no further indication for the single years.
} 
wheat areas, $24 \%$ in production and a yield growth from 14.1 to 16.3 hundredweight per hectare in 1938.

These data however have fairly divergent trends, as shown in Fig. 2 which summarizes the outcomes of this policy in the different "rural Italies". Besides showing the significant difference in yield levels between North and South, it highlights diverse kinds of performance. In general, vertical movements characterize two types of trends. The first involves clusters subject to orographic and climatic constraints, such as the Alps, Liguria, and to a certain extent also the Southern Apennines, the Messina Strait, Central Italy (Mezzadria), and the Province of Asti, where rural efforts increased yields (moderately) but could not expand the acreage because of the mountains and hilly ground. The other case is that of clusters, like the Veneto Plain and Lombardy, that had arable soil but preferred not to alter (or not to a great extent) their own crop mix. Here a large expansion of wheat cultivations interfered with well established, long-term crop equilibriums, and the Battaglia del grano was mostly the opportunity to make limited plots profitable. To some extent this is also the case of the Mezzadria cluster, where, notwithstanding the good increase in yields, the enlargement of the wheat arable area collided with the poor availability of suitable land and the complex balances of mixed farming. As regards Asti, the wheat area is even reduced: here the government policy seems to be almost ignored in favor of wine specialization, that represented the peculiar model of accumulation of the cluster.

Oblique and horizontal movements show a larger adhesion to the policy of the regime, albeit with consistent differences. A higher growing slope, similar above all to the case of Ferrara and partly to the Piedmont rice cluster, denotes ability and interest in capturing State incentives (Orlando 1984: 103). Here, and to a lesser extent in the Po Delta, the speculative choice to exploit government support was associated with a versatile agriculture, well-endowed with machinery and monetary capital, and ready to convert to other crops. Similar trends were also those adopted by Southern clusters, like Sardinia and the Sicilian ones, but with much lower yields and, especially in the latter case, by sacrificing more valuable crops. Four other Southern clusters, moreover, have an almost horizontal slope (Naples and Southern Arable even a downward trend), indicating the expansion of wheat in unsuitable soils, despite national efforts to improve seeds and fertilizers. Stable or declining yields mean the inability to adopt government policy successfully, even where large arable estates were traditionally addressed to wheat. Above all, the expansion of graingrowing areas took place at the expense of pastures or crops for animal feed, exacerbating the already existing imbalance between cereals and forages. Alternatively, it may indicate the abandonment of special crops in which Apulia and the province of Naples had traditionally invested.

Indeed, this picture suggests interesting albeit partial considerations, to integrate with the contemporary dynamics of other crops and, in particular, the specializations of the single clusters. Different products however do not allow a direct comparison, as they are not spread all over the country. Monetary values would permit the homogenization of various outputs, but these are not available for many crops and the different local markets. Moreover, they would be heavily influenced by the price structure and its strong fluctuations during the crisis. The agrarian change is therefore evaluated here in real terms, with reference to allocation and the effectiveness of cultivation, through unit yields rather than gross salable production. 
The performance of the various clusters is investigated through a specialization index. For each crop this index compares the weight of the cluster production on the national total with the similar weight for the whole cultivated area of the cluster (Tab. 4). Values greater than 2 define a crop specialization.

For each specialization, the 1923-1929 data are compared with the 1936-1938 average (Tab. 5, column a), and the difference between this and the national yield variation for the same time-span (column b) is analyzed. What emerges for the Alpine provinces is a substantial yield stability both in relative and absolute terms: in the case of apples, for instance, revenues drop but considerably less than at national level. In the Asti cluster vines maintain (or recover) stable returns, in contrast with the decline in the rest of Italy, and this explains their resilience to the expansion of wheat. Similarly, Liguria and Upper Tuscany, where the wheat extensions also regress slightly, show stable yields of olives which, on the contrary, are characterized by significant reductions on a national scale and particularly in the South. The trend in rice specializations in the Po Valley remains stable, while Low Lombardy increases its corn yield and the consistence of its cattle (bovines). Roughly stable returns or moderate regressions (at least in comparison with national trends) are recorded in Ferrara, as well as in the Veneto Plain and the Po Delta, where respectively vegetables and peaches hold, unlike the sharp decline highlighted at national level. On the contrary, yields of the Southern specializations fall: a sharp reduction, even greater than the national trend, affects the fruit crops of Naples, olive trees in the Southern Apennines, almonds in Apulia, tobacco in Lecce, the citrus fruits and olives of the Messina Strait, sheep in the Continental Arable areas and more moderately in Sardinia. Sicily shows a slightly better trend, especially for its central cluster, where almond trees record a reduction in line with the Italian average and broad beans grow in association with wheat (like in general also lower cereals, such as barley or oats, in the South).

The heterogeneous evolution of Italian agriculture in the Thirties can therefore be synthesized in a number of ways. What emerges is firstly a set of clusters which are able to react positively to the crisis, such as, in particular, Low Lombardy. Based on large and medium-large tenancy, this early case of agrarian capitalism is well endowed with monetary, mechanical and animal capital. It is characterized by a traditional, defined pattern of accumulation, relying on the rotation of wheat with maize in association with cattle and pigs, the production of butter and cheese, and a strict integration with the large market and industrial centers of the Po Valley. Although this agriculture is affected, it can react dynamically to the recession, capturing the State incentives related to wheat and fertilizers without deviating from its secular path of development. Therefore, by the late Thirties, most of its main outputs, from cereals to livestock, had either recovered or exceeded their 1929 levels.

The case of the Po Delta and especially the province of Ferrara is quite different. Here an industrial agriculture prevails, ready to adapt its crop orientation to the current opportunities, whether price fluctuations or government incentives. Being the result of the main and most effective land reclamation of the $20^{\text {th }}$ century, this rural environment is characterized by large companies, or even small and medium-sized farms, which in any case are strictly linked to the big transformation industries, above all sugar refining. This cluster offers a wider range of crops than Lombardy, and it is intensively cultivated because of the fertility of the soils and the good capital availability (albeit with no particular endowment of livestock capital). 
The other clusters of the Po Valley (as well as the plain portions of the Alpine region) are found partly in the trough between these patterns, with a productive organization similar to the Lombardy farmhouses but specialized in some commercial crops, such as rice, sugar beet or vegetables. Although not exclusive, large estates prevail in the rice area, which is particularly affected by the fall in export prices, only partially compensated by the limited extension of wheat production. Negative trends, however, are restrained here also thanks to the consortium organization of the large producers and the support it obtains from the government in terms of protection on domestic markets and incentives for exportation (Brianta 1983). Small and mediumsized farming, which is predominant elsewhere and particularly in the Eastern plains, is more related to family and local consumption, alongside commercial and industrial cultivations that perform equally well. Both the rice and the Veneto clusters share partially capitalistic features, but they are less dynamic than Lombardy and with only limited flexibility in crop choices.

Asti is an unusual case. Its territory, hilly and characterized by small and medium-sized holdings, offers limited space for cereals, which are however grown efficiently. The provincial agriculture is centered on an advanced viticulture, combining capital and product quality. Good market skills, cooperative ties and investment capabilities (also in the form of labor) allow the crisis in the wine sector to be handled, bridging the gap arising from the restriction of foreign markets.

These types of agriculture, located in the North and with a substantially positive performance in the Thirties, have good (or at least discreet) capital resources and produce commodities mostly for the domestic market, often protected or supported by the State.

A mirror trend characterizes export-led agriculture, based on crops largely traded abroad and highly sensitive to the fall in international prices (Federico et al. 2011: 45ff.). This is the case of several Southern clusters, such as the Specialized Apulia, Sicily with its different regions, and even the province of Naples. These are mostly rich agricultural areas, where conspicuous investments were made, especially in woody crops (citrus fruits, vines, olive trees, almonds), from the late 18th century and were later intensified with the agrarian crises at the end of the $19^{\text {th }}$ century (Bevilacqua 2000). In the 1930s the specializations of these clusters were hard hit by the price downturn. Their heavy reliance on international trade prevented them from following the example of Piedmont wine which, partly as a result of the high-quality standards achieved, was able to limit the quantities produced and to focus on domestic markets for higher priced or luxury goods. Olive oil is also paradigmatic: while Liguria and Tuscany improved their limited production and the relative yields, introducing the first bottled brands in the country, crops declined in the Southern areas, at least excluding major producers like central Apulia. The case of tobacco in Lecce is only partly different: its massive introduction was supported by the State, leading to the construction in that town of the largest Italian manufacturing plants. These pioneering investments, however, were frustrated by the inefficiency of the leaf harvest, commercial backwardness, and the introduction of a variety of tobacco which did not reflect consumer tastes (Mastrolia 2008: 145). This triggered a crisis in the market for Apulia tobacco in the Thirties in favor of, for example, the Verona production, which was more popular with domestic customers. As regards the province of Naples, its richness relied on the high fertility of partly volcanic soils and a centuries-old agricultural tradition that, besides woody crops, had widely developed horticulture, i.e. the other main vocation of Mediterranean environments. Such a highly diversified rural economy (Tino 
1997) reacted to the crisis by expanding the protected wheat crops at the expense of its ability to exploit other vocations, which would have been more valuable in the future.

Finally, similar orientations are adopted in Specialized Apulia and in general in all the Southern clusters, that follow the cereal policy introduced by the regime and sacrifice - wherever possible past investments in specialized crops. It is noticeable that, where the clusters seem to be favorable and traditionally linked to wheat, such as in the Southern Arable area, yields record even an overall decrease. The point is that this cluster, like others in the South, mainly practiced extensive agriculture, based on little or no investment ${ }^{4}$, inefficient management and labor-intensive techniques, in poorly infrastructured and economically backward contexts. State support fostered an increase in the grain surfaces without substantially elevating their low yields, given the poor versatility of these systems and the expansion to lands often less suitable for cereals (Rossi Doria 1953).

Only one partial exception is represented by Sicily, and especially the Sicily-Almond area, where large cereal estates benefitted from both the peculiar diffusion of the traditional rotation "wheatbroad beans" and a widespread use of fertilizers (Tab.6). Finally, as regards Sardinia, the government incentives and land reclamations completed by the Fascist regime fueled revenue increases, which however remained confined to very low levels.

In the other clusters of mountainous and hilly inland areas, agriculture is often linked to subsistence and the grain policy is less effective owing to the lack of arable land. Especially in the South, the balance of the crisis is heavily negative, as shown by the dramatic losses in the few fields of specialization, such as olives. The difficulties in herding sheep, based on transhumance, also have an unfavorable impact in this area. In the case of the Messina Strait, the gap with the mountain clusters in the North is significant, although the performance of the Alpine provinces is improved by the presence of plains. In fact, during the Thirties, all the mountain areas, both in the North and in the South, experienced an intensification of the depopulation process which had already started during the Great Depression at the end of the 19th century (Inea 1938).

In Central Italy, finally, the recession had yet another effect. Here, the lack of specialization reflects a model based on the mixed cropping of the small farm, markedly oriented toward domestic consumption and local markets. This relative isolation reduces the burden of the crisis, while the flexibility of family conduction allows discreet yield standards to be maintained, and provokes a positive reaction to the solicitations of the State grain policy, at least in terms of yields. On the other hand, the geographic constraints of a hilly ground limit the intensification of cultivation, which nonetheless occurs locally, for instance in the most dynamic areas of Tuscany. A generalized development (similar to the example of wine specialization in Piedmont) is here rather hampered by the features of the sharecropping system, its landowners' low propensity to invest, the delicate polyculture equilibrium, and ultimately the relative lack of involvement in a modern market logic. Confirming its Aurea mediocritas (Jacini 1881), this cluster nonetheless shows a peculiar resilience to the crisis and the ability to adapt, albeit passively, to changing circumstances.

\footnotetext{
${ }^{4}$ In grain regions, lack of proper organic manure and extensive cereal rotations produces a strong depletion of soil fertility (Tino 2016).
} 


\section{Concluding considerations}

As can be seen from the above analysis, during the Thirties the rural geography of the peninsula had very diverse dynamics. Export-led agriculture was heavily hit by the fall in international prices, while production oriented to domestic protectable markets had fewer difficulties in recovering, in particular as regards those goods addressed to high quality or local demand, such as Piedmont wines and the outputs of Central Italy Mezzadria, respectively. In a similar way, the Battaglia del grano brought large benefits to some areas, like the province of Ferrara, which were equipped to take advantage of it, whereas it had little or no impact on others, like the Southern Apennines and the mountain districts in general. Especially in the Mezzogiorno, moreover, this policy produced widespread yield increases, but at levels that remained anyway low both if compared to the rest of the country and in absolute terms. For several Southern clusters, therefore, it had - at least in the medium term - the negative effect of damaging vocations for specialized crops. In some other contexts, such as the province of Asti, the wheat policy was finally almost ignored by farmers who continued their original path of accumulation.

It is evident that this assumption has larger implications. Territorial disaggregation can highlight trends and dynamics hidden at national or regional level (Baffigi 2013, Federico 2003). This investigation allowed the identification of a set of homogeneous agricultural clusters, that show the differentiated dynamics fostered by the crisis and the policies adopted to counter it much more than the national (or regional) aggregate, in which divergent trends and performances may compensate each other and partly disappear. The scale of the breakdown remains, however, an open question, depending on data availability as well as the issues and perspectives adopted. In the present case, the provincial unit (combined with the agrarian regions for Pca) is also coherent with evidence in the contiguous field of manufacturing, that underlines how post-Unification "industrialization was markedly sub-regional" (Ciccarelli, Fenoaltea 2010: 6). At the same time, a more detailed disaggregation would collide with a lack of time series for farm production and the scarcity of further homogeneous data below province level.

The result of this work is however consistent with existing literature. It allows the identification, within a coherent (albeit approximated) territorial framework, of a set of different productive formations, which can be assimilated to more general social-economic types: the agrarian capitalism of Low Lombardy, an industrial agriculture in the Ferrara area, some peasant economies in Piedmont and Veneto, the export-led specialized systems of the South, different mountain rural economies, the sharecropping of Central Italy, the large cereal estates of the Mezzogiorno.

The assessment of this variety may have broader meanings and be especially relevant for developing countries, similar to Italy in the Thirties, where economic and social patterns are particularly dualistic (Gerschenkron 1972) or even - as has been shown so far - pluralistic.

The assumption that "rural Italies" experienced the recession diversely is also relevant for the question raised initially, regarding the relationship between agriculture and crisis in the interwar period. It suggests that the depression cycle hit some parts of Italian agriculture much more than national data point out, and even more so if considered in conjunction with related policies. At the same time, the disaggregation shows how for other rural areas the recessive dynamics of the 
Thirties had a limited impact, in some cases also due to the effect of the policies deployed by the regime. Further analysis is needed to assess more precisely the relative impact of the crisis and the protectionist measures on the local dynamics of the various clusters. Likewise, other investigations are necessary to analyze employment changes and income trends, which on one hand require the reconstruction of the price structure in Italian agriculture and its local articulation in the interwar period, and on the other would allow us to estimate the weight of the rural crisis on the general economic and employment equilibriums of the single clusters.

Nevertheless, some of the causes of the different performance of Italian agriculture may be highlighted here provisionally based on the above analysis and the existing literature.

Firstly, the geographical and territorial constraints obviously have a relevant role, together with the agricultural vocations they often imply, from the "high farming" of the Northern plains to the Mediterranean woody crops or horticulture. A second determinant is clearly capital in its various forms, monetary, mechanical or animal, along with the capacity and propensity to invest. Between the two wars, Italian agriculture made relevant investments, in addition to significant cost reductions (Nützenadel 2001). Both, however, were probably very locally diversified and deserve to be analyzed in relation to the different clusters identified here. A third key factor is, finally, the social and economic dynamism of the contexts. The possibility of integration with the secondary sector into agro-industrial systems, as well as efficient infrastructures and marketing frameworks, and more in general the associative and entrepreneurial dynamism of the local social texture (Bevilacqua 1997: 60ff.), represented crucial elements for reacting to the recession and exploiting the government policies. This third element, in other words, was not strictly to do with agriculture itself, but rather with the more general causes of the South-North divide in the country, recently identified in the type of participation in the industrialization process from the 1880s onwards (Daniele, Malanima 2011), the different attitude of institutions and ruling classes in various parts of the country (Felice 2014), or the delays in Italian industrial growth and the development of the country's human capital (Fenoaltea 2006: 266).

Despite its partial nature, the present study, based on real outputs and physical productivity, is already able to highlight how the recession of the Thirties represents a crucial turning point, that anticipates later trends, such as the crisis in specialized and export-led agriculture in the South or the farming decline in some mountain areas. Thus, the depression and its connected policies not only accelerated some previous dynamics but also contributed substantially to transforming into a permanent gap what, until that time, had often been seen as a different growth process, albeit with a diverging pace and varying features. 
Table 1 - Variable for PCA

\begin{tabular}{|c|c|c|}
\hline Variable & Definition & Unit \\
\hline$A f a$ & Agricultural and forestry area (Afa) & share on Land area (\%) \\
\hline Ext_RA & Mountain Region (Afa) & share on Afa (\%) \\
\hline Ext_Gini & Crop Concentration ratio (Area) & Gini Index \\
\hline Bovines & Bovine Intensity & Units per Hectare \\
\hline Equines & Equine Intensity & Units per Hectare \\
\hline Pigs & Pig Intensity & Units per Hectare \\
\hline Sheep & Sheep Intensity & Units per Hectare \\
\hline Goat & Goat Intensity & Units per Hectare \\
\hline SoftWheat_S & Soft Wheat area (main crop) & share on $A f a(\%)$ \\
\hline DurumWheat_S & Durum Wheat area (main crop) & share on $A f a(\%)$ \\
\hline Barley_S & Barley area (main crop) & share on $A f a(\%)$ \\
\hline Rye_S & Rye area (main crop) & share on $A f a(\%)$ \\
\hline Oats_S & Oat area (main crop) & share on Afa (\%) \\
\hline Rice_S & Rice area (main crop) & share on $A f a(\%)$ \\
\hline Maize_S & Maize area (main crop) & share on $A f a(\%)$ \\
\hline SugarBeet_S & Sugar Beet area (main crop) & share on Afa (\%) \\
\hline Tobacco_S & Tobacco area (main crop) & share on $A f a(\%)$ \\
\hline Potato_S & Potato area (main crop) & share on Afa (\%) \\
\hline Tomato_S & Tomato area (main crop) & share on Afa (\%) \\
\hline RotMeadows_S & Rotated Meadows area (main crop) & share on $A f a(\%)$ \\
\hline PermMeadows_S & Permanent Meadows area (main crop) & share on Afa (\%) \\
\hline OliveTr_S & Olive Tree area (main crop) & share on Afa (\%) \\
\hline Orange_S & Orange area (main crop) & share on Afa (\%) \\
\hline Lemon_S & Lemon area (main crop) & share on Afa (\%) \\
\hline Apple_S & Apple area (main crop) & share on Afa (\%) \\
\hline Peach_S & Peach area (main crop) & share on Afa (\%) \\
\hline Almond_S & Almond area (main crop) & share on $A f a(\%)$ \\
\hline BroadBeans_S & Broad Beans area (main crop) & share on $A f a(\%)$ \\
\hline HempSeed_S & Hemp Seed area (main crop) & share on Afa (\%) \\
\hline Hemp_S & Hemp area (main crop) & share on Afa (\%) \\
\hline Chestnut_S & Chestnut area (main crop) & share on Afa (\%) \\
\hline Arable_S & Arable area (main crop) & share on $A f a(\%)$ \\
\hline Pastures_S & Pastures area (main crop) & share on Afa (\%) \\
\hline Wooden_S & Wooden area (main crop) & share on $A f a(\%)$ \\
\hline Wood_S & Wood area (main crop) & share on $A f a(\%)$ \\
\hline Uncult_S & Uncultivated area (main crop) & share on $A f a(\%)$ \\
\hline Vine_S & Vine area (main crop) & share on $A f a(\%)$ \\
\hline SoftWheat_Y & Soft Wheat Yields (main and mixed crops) & quintal per hectare \\
\hline DurumWheat_Y & Durum Wheat Yields (main and mixed crops) & quintal per hectare \\
\hline Barley_R & Barley Yields (main and mixed crops) & quintal per hectare \\
\hline Rye_R & Rye Yields (main and mixed crops) & quintal per hectare \\
\hline Oats_R & Oat Yields (main and mixed crops) & quintal per hectare \\
\hline Maize_Y & Maize Yields (main and mixed crops) & quintal per hectare \\
\hline Potato_Y & Potato Yields (main and mixed crops) & quintal per hectare \\
\hline Tomato_Y & Tomato Yields (main and mixed crops) & quintal per hectare \\
\hline Vine_Y & Vine Yields (main crop) & quintal per hectare \\
\hline OliveT_R & Olive Tree Yields (main crop) & quintal per hectare \\
\hline Owners & Farm Owners & share on Agricultural labour force (\%) \\
\hline Tenants & Farm Tenants & share on Agricultural labour force (\%) \\
\hline Sharecr. & Sharecroppers & share on Agricultural labour force (\%) \\
\hline Laborers & Farm Laborers & share on Agricultural labour force (\%) \\
\hline
\end{tabular}


Table 2 - Rotated Factor Loadings and proportion explained variance (\%)

\begin{tabular}{|c|c|c|c|c|c|c|c|c|c|c|}
\hline \multirow[b]{3}{*}{ Variable } & \multicolumn{10}{|c|}{ Factor } \\
\hline & $A$ & $B$ & $C$ & $D$ & $E$ & $F$ & $G$ & $H$ & $J$ & $K$ \\
\hline & $\begin{array}{l}\text { Po Valley } \\
\text { Intensive }\end{array}$ & $\begin{array}{l}\text { Extensive } \\
\text { (Southern) }\end{array}$ & Mountain & Woody & $\begin{array}{l}\text { Multi- } \\
\text { crop }\end{array}$ & $\begin{array}{c}\text { Industrial } \\
\text { Farming }\end{array}$ & $\begin{array}{l}\text { Citrus } \\
\text { Fruits }\end{array}$ & $\begin{array}{l}\text { Cereal/ } \\
\text { Almonds }\end{array}$ & Potato & Rice \\
\hline$\%$ variance & 25,01 & 13,70 & 7,75 & 4,76 & 4,10 & 3,54 & 2,99 & 2,81 & 2,55 & 2,34 \\
\hline$A f a$ & 907 & 240 & 223 &,- 112 &, 044 &,- 101 &,- 014 &, 005 &,- 031 &,- 001 \\
\hline Ext_RA &, 578 & 151 & 257 &,- 203 & ,030 & 177 &,- 163 & ,135 &, 050 & 198 \\
\hline Ext_Gini & ,908 &, 027 & 195 &,- 033 &, 088 & -189 &,- 045 & 101 &,- 003 &, 008 \\
\hline Bovines & ,714 &,- 517 &,- 241 & ,130 &,- 004 &,- 087 & ,142 & ,037 &,- 143 &,- 025 \\
\hline Equines & 635 & ,429 &,- 267 & 264 &,- 065 & -129 & ,184 &,- 015 & ,224 & ,049 \\
\hline Pigs & ,619 &,- 333 &,- 351 &,- 104 & 144 &,- 008 & 229 &,- 046 &,- 210 &,- 054 \\
\hline Sheep & ,306 &, 556 & ,218 & -470 &,- 084 &, 041 & ,008 &,- 280 &,- 099 &,- 029 \\
\hline Goat & ,256 & 630 & ,310 & 142 &,- 040 & 221 & 293 &,- 196 &,- 092 &,- 060 \\
\hline SoftWheat_S & 689 &,- 280 &,- 335 &,- 306 & 134 &,- 121 &,- 008 &,- 218 & ,029 &,- 062 \\
\hline DurumWheat_S & 120 & ,740 &,- 206 &, 004 &,- 298 &,- 166 &, 056 & 358 & ,137 &,- 027 \\
\hline Barley_S & ,223 & ,710 &,- 164 &,- 114 &,- 062 & -123 &,- 111 & 240 & 051 &,- 114 \\
\hline Rye_S & ,312 &,- 310 & ,235 & 429 &,- 312 &,- 228 &,- 077 &,- 050 & , 105 & 111 \\
\hline Oat_s & ,312 & 498 &,- 123 &,- 096 & -196 &,- 066 &,- 403 &,- 276 &,- 091 &,- 032 \\
\hline Rice_S & 136 &,- 125 &,- 108 & 170 &,- 271 &,- 102 &,- 156 & -,099 &,- 372 &, 558 \\
\hline Maize_S & ,617 &,- 413 &,- 228 & 051 &,- 095 &,- 206 &, 087 &,- 306 & 164 &,- 093 \\
\hline SugarBeeet_S & 282 & -183 & -281 &, 004 &, 003 & 627 &,- 242 & ,212 &, 078 & 072 \\
\hline Tobacco_S & , 124 & 159 &,- 133 & 116 & 236 &, 033 &,- 478 &,- 320 & 010 &,- 149 \\
\hline Potato_S & 399 &,- 185 & ,308 &, 025 &,- 016 & -100 & ,093 &,- 245 & ,527 & 071 \\
\hline Tomato_S & ,301 &, 070 &,- 304 & 082 & 098 & 209 & ,135 &, 088 &,- 032 &, 052 \\
\hline RotMeadows_S & 611 &,- 355 &,- 488 &,- 206 & ,063 &,- 078 & 120 & 084 &,- 166 & 017 \\
\hline PermMeadows_S & ,376 &,- 463 & 264 & ,383 &,- 237 &,- 191 &,- 054 & 136 & 026 &,- 137 \\
\hline OliveTr_S & ,135 & ,523 & 011 & 295 & ,472 &,- 077 &,- 323 &,- 234 &,- 036 & 156 \\
\hline Orange_s & 098 & 327 &,- 040 & 317 & 098 & 099 & ,467 &, 076 &,- 080 & , 169 \\
\hline Lemon_S & 030 & 216 &,- 016 & 301 & 154 & 077 & 412 &,- 029 &,- 118 & 095 \\
\hline Apple_S & 081 &,- 023 & 137 & 237 &, 069 &, 040 &,- 015 & 130 &,- 160 &,- 441 \\
\hline Peach_S & ,270 &,- 083 &,- 177 & ,096 & ,227 & ,364 &, 055 &,- 069 & ,300 &,- 007 \\
\hline Almond_S & ,066 & ,533 &,- 158 & 264 & 107 & -190 &,- 116 & ,342 &, 078 & ,176 \\
\hline BroadBeans_S & , 165 & 641 &,- 208 & -140 & 199 &,- 267 &, 016 & ,343 & 209 &, 004 \\
\hline HempSeed_S & 060 &,- 026 & -101 &,- 007 &,- 021 &, 042 & 091 & -190 & ,318 & -111 \\
\hline Hemp_S & , 188 &,- 091 &,- 198 &, 030 &,- 024 & ,598 &,- 164 & , 140 & 298 & ,102 \\
\hline Chestnut_S & ,104 &,- 069 & 480 &,- 189 & ,350 &,- 059 &, 001 & ,098 & 200 & ,375 \\
\hline Arable_S & 814 & 079 &,- 465 & -199 &,- 112 &,- 129 &,- 005 &,- 020 &, 039 &, 023 \\
\hline Pastures_S & 196 & 381 & ,554 &,- 221 &,- 259 & 206 &, 068 &,- 091 &,- 228 &,- 141 \\
\hline Wooden_S & ,257 & 605 &,- 023 & 485 &, 503 &,- 097 &,- 118 &,- 042 &,- 038 &,- 036 \\
\hline Wood_S & ,332 &,- 140 & ,751 &,- 184 & 231 &,- 060 &,- 005 & ,098 & 059 & 116 \\
\hline Uncult_s & ,236 &, 026 & 658 &,- 010 &, 005 & ,200 & 091 & 114 & -133 &,- 049 \\
\hline Vine_S & ,412 & ,195 &,- 092 & ,246 & ,530 &,- 069 &, 058 & ,046 &,- 058 &,- 292 \\
\hline SoftWheat_Y & ,861 &,- 281 &, 039 &,- 002 & -124 & 019 &,- 087 & 134 &,- 103 &,- 036 \\
\hline DurumWheat_Y & ,212 & ,762 &,- 065 &,- 082 &,- 267 &,- 008 &,- 026 &,- 120 & ,018 &,- 061 \\
\hline Barley_R & ,702 & 121 &, 005 &,- 196 &, 022 & ,213 &,- 081 & 176 &, 056 &,- 246 \\
\hline Rye_R & 663 &,- 463 & 180 & 203 &,- 091 & 092 &,- 075 & ,057 &, 085 &,- 039 \\
\hline Oat_R & 840 &,- 072 &,- 002 &, 007 & , 115 &, 058 &,- 088 &, 043 &,- 051 &,- 031 \\
\hline Maize_Y & ,792 &,- 392 & 133 & ,155 &,- 003 & ,026 &,- 077 & ,019 &,- 118 & , 071 \\
\hline Potato_Y & ,781 & -,196 & ,091 & 156 &,- 065 & 164 &,- 011 & ,091 &,- 122 &,- 074 \\
\hline Tomato_Y & 658 &,- 045 & -149 & -126 & ,112 &, 040 & ,114 &,- 100 &, 029 & , 167 \\
\hline Vine_Y $Y$ & ,797 &, 085 & 149, &,- 045 &, 042 &,- 068 &,- 029 &, 003 &,- 005 & 148 \\
\hline OliveT_R & 255 & 644 & 193 &,- 125 & 014 & 172 & ,275 &,- 175 &, 038 & 049 \\
\hline Owners &, 528 &,- 055 & ,624 & 101 &,- 027 &,- 195 &,- 071 & ,070 & 107, &,- 149 \\
\hline Tenants & 618 & , 176 &,- 090 & 227 &,- 361 & 113 & , 167 &,- 270 & 143 &, 029 \\
\hline Sharecr. & ,442 &,- 079 &,- 104 &,- 593 & 408 & -,193 & ,106 & 115 &,- 043 & ,039 \\
\hline Laborers & 620 &, 519 &,- 108 & 158 & -107 & ,216 &,- 124 &,- 018 &,- 241 &, 106 \\
\hline
\end{tabular}

Source: Our Elaboration on Istat data (Catasto agrario 1929, Censimento 1931) 
Fig. 1 - Cluster dendrogram (average linkage clustering)

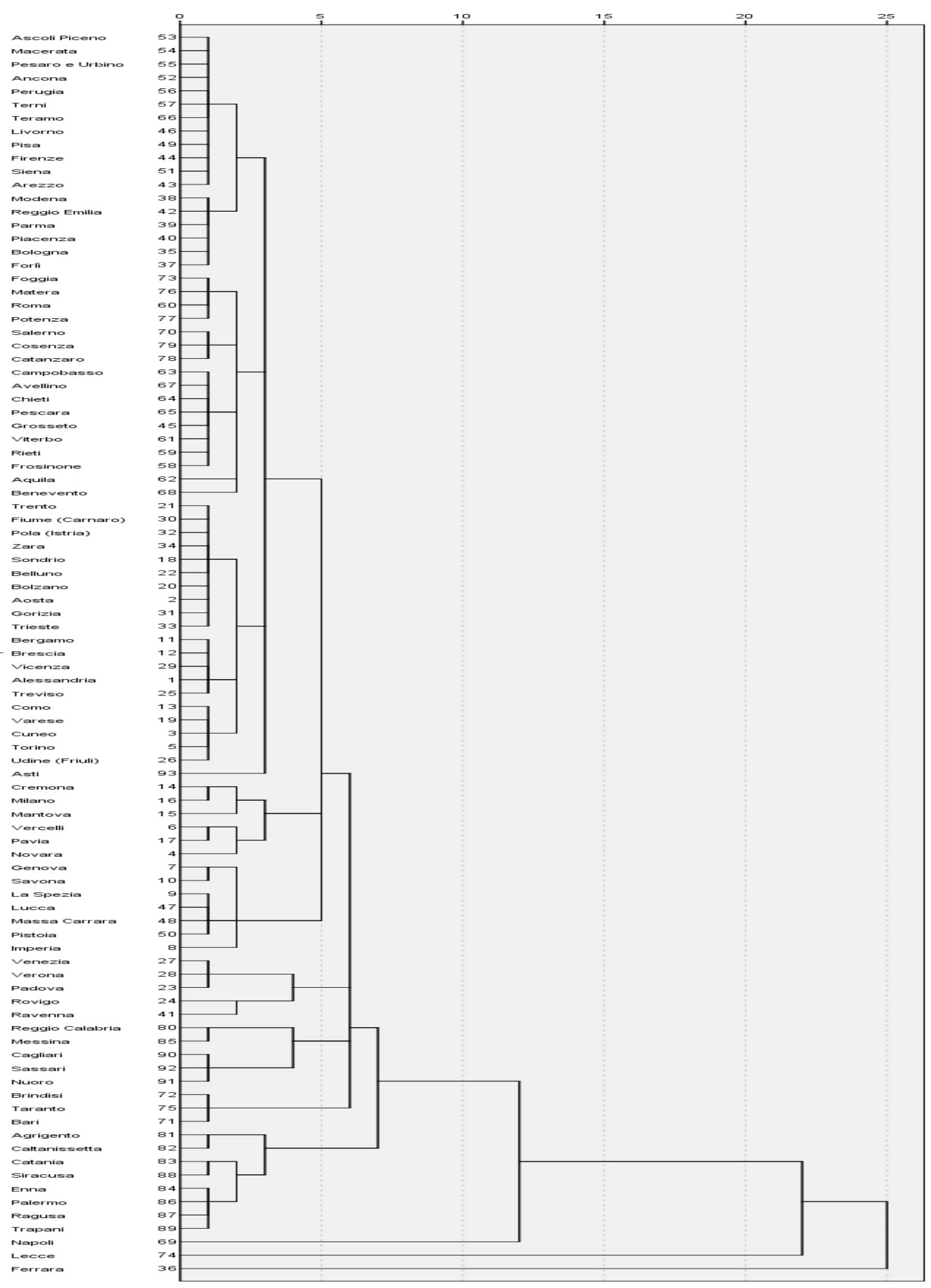


Tab.3: Average scores matrix for cluster of the 10 extracted components

\begin{tabular}{|l|r|r|r|r|r|r|r|r|r|r|}
\hline Cluster & ACP1 & ACP2 & ACP3 & ACP4 & ACP5 & ACP6 & ACP7 & ACP8 & ACP9 & ACP10 \\
\hline Alpine Arc & 0,489 & $-0,731$ & 1,187 & 0,453 & $-0,497$ & $-0,134$ & $-0,289$ & 0,610 & $-0,047$ & $-0,478$ \\
Asti & 0,910 & $-0,558$ & 0,237 & 1,304 & 1,498 & $-0,868$ & $-0,441$ & 0,715 & $-0,173$ & $-1,620$ \\
Rice Po Valley & 0,664 & $-0,833$ & 0,394 & 1,149 & $-1,200$ & $-0,481$ & $-0,655$ & 0,003 & $-1,853$ & 2,024 \\
Liguria High Tuscany & 0,139 & $-0,077$ & 1,735 & $-0,476$ & 1,727 & $-0,060$ & 0,038 & 0,179 & 1,278 & 2,133 \\
Low Lombardy & 1,679 & $-1,184$ & $-1,181$ & 0,530 & $-1,022$ & $-0,224$ & 0,079 & $-0,114$ & $-0,881$ & 0,651 \\
Veneto Plain & 1,419 & $-0,902$ & $-0,981$ & 0,431 & 0,054 & 1,688 & $-0,305$ & $-0,589$ & 1,092 & $-0,357$ \\
Po Delta & 1,215 & $-0,747$ & $-1,330$ & $-0,330$ & 0,365 & 3,106 & $-1,229$ & 1,490 & 0,001 & 0,486 \\
Ferrara & 0,583 & $-0,426$ & $-0,280$ & $-1,393$ & 0,757 & $-0,219$ & 0,135 & 0,353 & $-0,424$ & 0,045 \\
Mezzadria & 0,371 & 0,575 & 0,485 & $-0,546$ & $-0,119$ & 0,027 & 0,112 & $-1,043$ & 0,499 & 0,153 \\
South Appennine & 0,376 & 1,233 & 0,222 & $-0,791$ & $-1,163$ & 0,324 & $-0,537$ & $-1,164$ & $-0,492$ & $-0,280$ \\
South-Centre Arable & 1,475 & $-1,064$ & $-1,840$ & 0,076 & $-0,619$ & 7,354 & $-3,210$ & 2,802 & 2,541 & 1,538 \\
Naples & 1,381 & 0,521 & $-0,656$ & 1,486 & 0,148 & 3,080 & 1,089 & $-1,376$ & 4,101 & 0,488 \\
Specialized Apulia & 0,289 & 2,040 & $-0,300$ & 1,156 & 0,971 & $-0,552$ & $-2,505$ & $-0,270$ & $-0,502$ & 0,569 \\
Lecce & 0,182 & 2,485 & $-0,882$ & 1,669 & 2,955 & $-0,214$ & $-6,009$ & $-3,549$ & $-0,386$ & $-1,535$ \\
Messina Strait & 0,365 & 1,556 & 0,730 & 0,759 & 0,846 & 0,993 & 1,836 & $-1,168$ & $-0,985$ & 1,109 \\
Sicily-Almonds & 0,346 & 2,782 & $-1,112$ & 0,031 & $-0,868$ & $-1,641$ & 0,117 & 3,413 & 1,785 & 0,766 \\
Sicily & 0,348 & 2,095 & $-0,583$ & 0,254 & $-0,690$ & $-0,359$ & 0,811 & 1,636 & 0,364 & $-0,036$ \\
Sardinia & 0,217 & 1,395 & 1,278 & $-0,933$ & $-1,518$ & 1,746 & 0,880 & $-0,794$ & $-1,530$ & $-0,592$ \\
\hline
\end{tabular}


Fig. 2: Wheat Yields (Q/Ha) and area (\%AFA) in selected clusters - 1923-29 and 1936-38 (averages)

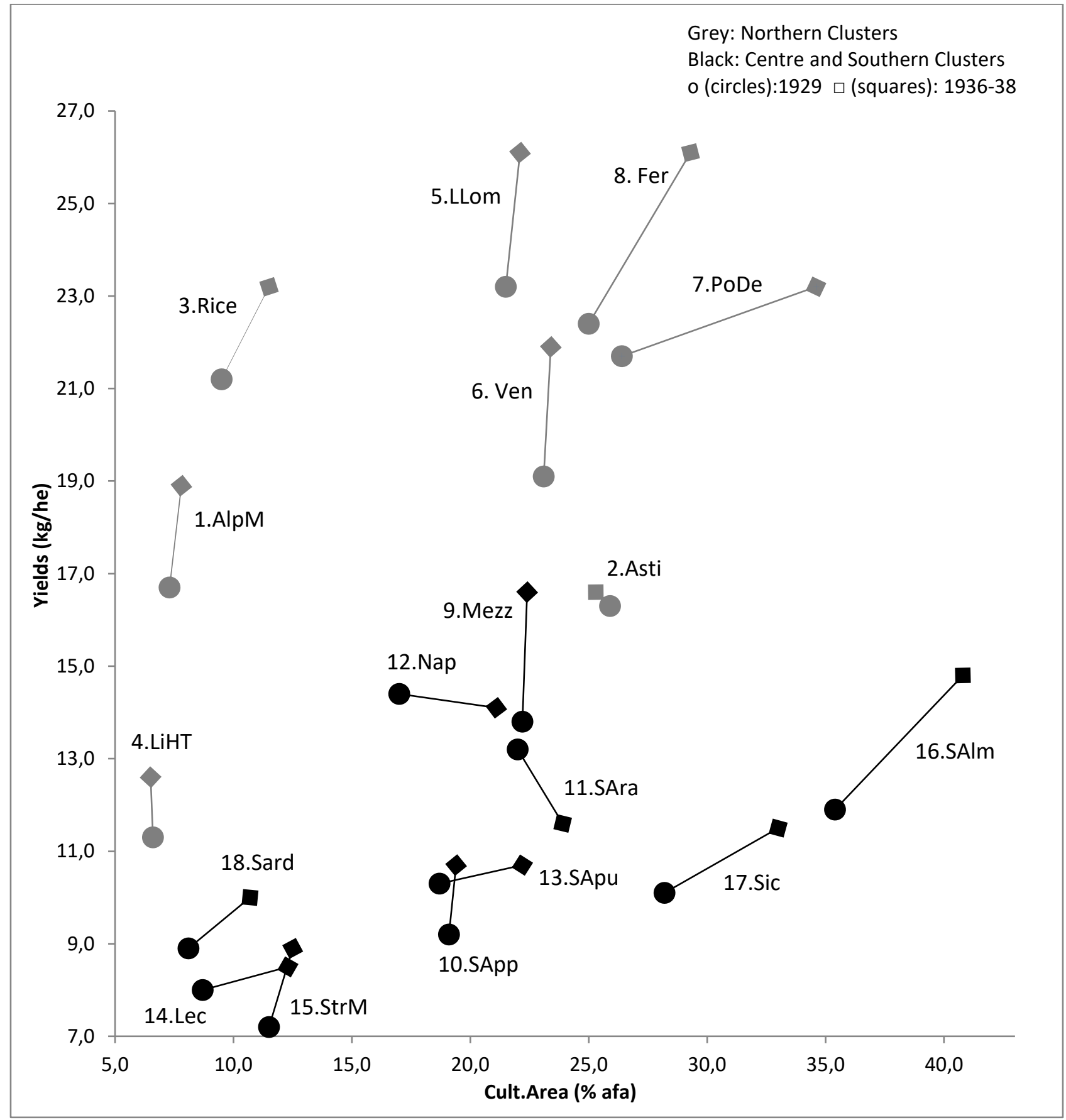

Source: Our Elaboration on Istat data (Cadastre 1929, ISTAT 1940) 
Tab.4 Farm Specialization Index of the selected clusters in 1929 (Italian average $=1$ )

\begin{tabular}{|c|c|c|c|c|c|c|c|c|c|c|c|c|c|c|c|c|c|c|}
\hline Clusters (nr.) & $\begin{array}{l}\frac{0}{2} \\
\frac{1}{2} \\
\frac{.}{2} \\
\frac{1}{2}\end{array}$ & 要 & 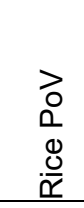 & 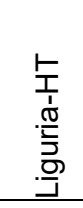 & 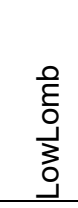 & $\begin{array}{l}\frac{.}{\sqrt{0}} \\
\frac{0}{0} \\
\frac{0}{0} \\
\frac{\mathbb{0}}{0} \\
\stackrel{0}{>}\end{array}$ & $\begin{array}{l}\frac{\pi}{ \pm} \\
\frac{0}{0} \\
0 \\
0 \\
\end{array}$ & 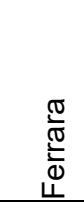 & $\begin{array}{l}\text {. } \\
\frac{\pi}{0} \\
\mathbb{N} \\
N \\
\mathbb{N} \\
\Sigma\end{array}$ & $\begin{array}{l}\frac{0}{0} \\
\frac{1}{1} \\
\frac{1}{3} \\
0 \\
\text { c }\end{array}$ & $\begin{array}{l}\frac{0}{0} \\
\frac{0}{0} \\
\frac{0}{4} \\
0 \\
0\end{array}$ & $\begin{array}{l}\text { O } \\
\mathbb{U} \\
Z\end{array}$ & 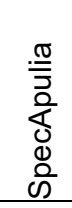 & $\begin{array}{l}0 \\
\text { d } \\
\end{array}$ & 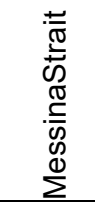 & $\frac{\dot{\varepsilon}}{\frac{\varepsilon}{\pi}}$ & $\frac{\lambda}{\overline{0}}$ & 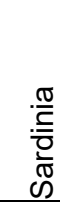 \\
\hline & 1 & 2 & 3 & 4 & 5 & 6 & 7 & 8 & 9 & 10 & 11 & 12 & 13 & 14 & 15 & 16 & 17 & 18 \\
\hline Wheat & 1,1 & 1,4 & 0,9 & 0,6 & 1,5 & 1,3 & 1,6 & 1,5 & 1,2 & 0,8 & 1,3 & 0,8 & 0,6 & 0,2 & 0,4 & 1,2 & 0,9 & 0,6 \\
\hline Barley & 0,5 & 0,0 & 0,0 & 0,3 & 0,1 & 0,2 & 0,6 & 0,2 & 0,7 & 0,6 & 1,2 & 1,0 & 1,0 & 2,8 & 0,8 & 1,7 & 2,7 & 3,3 \\
\hline Oats & 0,5 & 0,3 & 1,2 & 0,3 & 0,8 & 0,5 & 0,7 & 0,5 & 0,5 & 1,2 & 2,9 & 1,2 & 2,4 & 1,1 & 0,2 & 0,3 & 0,7 & 1,1 \\
\hline Rye & 4,9 & 2,1 & 4,4 & 0,5 & 1,6 & 0,8 & 0,5 & 1,1 & 0,2 & 0,4 & 0,1 & 1,7 & 0,0 & 0,0 & 0,7 & 0,0 & 0,1 & 0,0 \\
\hline Maize & 2,9 & 1,6 & 1,9 & 0,8 & 3,4 & 3,1 & 0,7 & 0,8 & 0,7 & 0,8 & 0,4 & 0,9 & 0,0 & 0,0 & 0,1 & 0,0 & 0,0 & 0,1 \\
\hline Rice & 0,0 & 0,0 & 27,2 & 0,0 & 4,1 & 0,4 & 1,0 & 0,9 & 0,2 & 0,0 & 0,0 & 0,0 & 0,0 & 0,0 & 0,0 & 0,0 & 0,0 & 0,0 \\
\hline Sugar Beet & 0,3 & 0,0 & 0,0 & 0,1 & 1,2 & 5,3 & 20,7 & 13,8 & 0,8 & 0,2 & 0,0 & 0,0 & 0,0 & 0,0 & 0,0 & 0,0 & 0,0 & 0,0 \\
\hline Tobacco & 0,7 & 0,0 & 0,0 & 0,1 & 0,2 & 3,8 & 1,6 & 0,9 & 1,0 & 1,0 & 0,1 & 0,1 & 1,1 & 18,3 & 0,1 & 0,0 & 0,1 & 0,0 \\
\hline Tomato & 0,2 & 0,4 & 0,3 & 3,6 & 0,2 & 0,4 & 3,4 & 1,0 & 1,8 & 0,8 & 0,6 & 7,5 & 0,7 & 0,4 & 0,7 & 1,2 & 0,6 & 0,3 \\
\hline Potato & 2,5 & 0,9 & 0,6 & 3,1 & 0,4 & 0,9 & 0,5 & 0,4 & 0,7 & 1,5 & 0,4 & 7,3 & 0,1 & 0,2 & 0,4 & 0,0 & 0,1 & 0,1 \\
\hline Broad Bean & 0,1 & 0,4 & 0,1 & 0,3 & 0,0 & 0,0 & 0,2 & 0,0 & 0,5 & 1,2 & 1,2 & 1,3 & 1,8 & 0,2 & 0,4 & 5,2 & 2,4 & 1,4 \\
\hline Hemp & 0,2 & 0,0 & 0,0 & 0,1 & 0,1 & 0,1 & 4,3 & 3 & 1,1 & 0,0 & 0,0 & 17,0 & 0,0 & 0 & 0,0 & 0,0 & 0,0 & 0,0 \\
\hline Cabbage & 2,1 & 1,0 & 0,6 & 5,3 & 2,5 & 2,5 & 0,2 & 0,0 & 0,4 & 0,6 & 1,9 & 3,1 & 0,2 & 0,7 & 0,8 & 0,0 & 0,3 & 0,2 \\
\hline Vine & 1,2 & 2,8 & 1,1 & 2,5 & 0,2 & 1,1 & 1,2 & 0,2 & 1,3 & 0,6 & 0,6 & 2,8 & 1,2 & 1,3 & 1,3 & 0,5 & 0,9 & 0,4 \\
\hline Olive tr. & 0,0 & 0,0 & 0,0 & 3,7 & 0,0 & 0,0 & 0,0 & 0,0 & 0,3 & 2,0 & 0,9 & 1,5 & 2,9 & 0,9 & 5,2 & 0,9 & 0,9 & 0,6 \\
\hline Oil & 0,0 & 0,0 & 0,0 & 3,9 & 0,0 & 0,0 &, 0 & 0 & 0,4 & 1,9 & 1,1 & 1,1 & 3,1 & 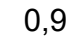 & 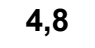 & 1,0 & 0,9 & 0,5 \\
\hline Wine & 1,3 & 3,2 & 1,2 & 2,5 & 0,2 & 1,1 & 1,3 & 0,2 & 1,3 & 0,6 & 0,6 & 2,8 & 1,3 & 1,4 & 1,2 & 0,5 & 0,9 & 0,4 \\
\hline Orange & 0,0 & 0,0 & 0,0 & 0,1 & 0,0 & 0,0 & 0,0 & 0,0 & 0,0 & 0,6 & 0,5 & 2,8 & 0,0 & 0,2 & 12,3 & 0,8 & 5,4 & 0,4 \\
\hline Lemon & 0,0 & 0,0 & 0,0 & 0,0 & 0,0 & 0,0 & 0,0 & 0,0 & 0,0 & 0,1 & 0,1 & 0,4 & 0,0 & 0,0 & 21,2 & 0,1 & 5,5 & 0,0 \\
\hline Apple & 3,4 & 0,1 & 1,5 & 1,7 & 0,1 & 0,9 & 10 & 0,9 & 0,6 & 1,0 & 0,3 & 5,5 & 0,0 & 0,0 & 0,7 & 0,1 & 0,5 & 0,2 \\
\hline Peach & 1,2 & 0,5 & 0,4 & 8,9 & 0,3 & 5,6 & 4,7 & 1,5 & 0,5 & 0,2 & 0,2 & 12,2 & 0,2 & 0,2 & 0,6 & 0,1 & 0,3 & 0,2 \\
\hline Almond & 0,0 & 0,0 & 0,0 & 0,1 & 0,0 & 0,0 & 0,0 & 0,0 & 0,1 & 0,2 & 0,4 & 0,0 & 7,0 & 0,1 & 0,7 & 10,6 & 2,0 & 1,1 \\
\hline Chestnuts & 1,6 & 0,1 & 1,0 & 20,9 & 0,0 & 0,1 & 0,1 & 0,0 & 0,9 & 1,1 & 0,2 & 1,2 & 0,0 & 0, & 0,9 & 0,0 & 0,0 & 0,2 \\
\hline Rot.Meadow & 1,5 & 0,9 & 2,5 & 0,4 & 3,6 & 1,7 & 2,3 & 2,5 & 1,9 & 0,3 & 0,1 & 0,2 & 0,0 & 0,0 & 0,3 & 0,1 & 0,3 & 0,0 \\
\hline Perm.Meadow & 5,9 & 3,0 & 2,3 & 1,0 & 2,4 & 0,7 & 0,5 & 0,6 & 0,3 & 0,0 & 0,0 & 0,1 & 0,0 & 0,0 & 0,0 & 0,0 & 0,0 & 0,0 \\
\hline Pastures & 1,9 & 0,0 & 0,2 & 0,7 & 0,0 & 0,1 & 0,1 & 0,1 & 0,3 & 0,7 & 2,2 & 0,2 & 0,6 & 0,2 & 0,8 & 0,3 & 0,4 & 6,4 \\
\hline Milk & 3,0 & 1,3 & 2,7 & 2,0 & 4,2 & 1,2 & 0,8 & 0,7 & 1,0 & 0,3 & 0,2 & 0,8 & 0,1 & 0,1 & 0,3 & 0,0 & 0,1 & 0,4 \\
\hline Horses & 1,5 & 1,1 & 1,7 & 1,1 & 2,9 & 1,2 & 1,1 & 0,9 & 0,7 & 0,6 & 1,0 & 3,0 & 1,0 & 0,8 & 0,3 & 0,6 & 0,7 & 1,4 \\
\hline Equines & 1,0 & 0,6 & 0,9 & 1,3 & 1,5 & 0,9 & 0,8 & 0,5 & 0,5 & 1,0 & 1,1 & 2,2 & 0,9 & 0,8 & 1,3 & 1,7 & 1,5 & 1,0 \\
\hline Bovines & 2,6 & 1,5 & 1,9 & 1,6 & 2,5 & 1,5 & 1,3 & 1,3 & 1,3 & 0,4 & 0,3 & 0,5 & 0,1 & 0,1 & 0,5 & 0,1 & 0,2 & 0,8 \\
\hline Pigs & 1,5 & 0,6 & 1,2 & 0,9 & 1,9 & 1,0 & 1,4 & 0,9 & 1,8 & 0,8 & 0,5 & 1,2 & 0,1 & 0,0 & 0,7 & 0,1 & 0,1 & 0,7 \\
\hline Sheep & 0,4 & 0,1 & 0,1 & 1,2 & 0,0 & 0,1 & 0,1 & 0,2 & 0,8 & 1,3 & 2,0 & 0,5 & 0,8 & 0,5 & 0,8 & 0,4 & 0,5 & 4,6 \\
\hline Goat & 0,9 & 0,6 & 0,5 & 1,1 & 0,1 & 0,3 & 0,1 & 0,0 & 0,1 & 1,3 & 1,2 & 1,1 & 0,6 & 0,5 & 4,1 & 0,9 & 1,0 & 5,3 \\
\hline
\end{tabular}

Source: Our Elaboration on Istat data (Cadastre 1929) 
Tab.5: Yields of cluster specialized crops (a: variation 1923/29-1936/38, livestock only 1929-1936/38; b: difference with Italian variation)

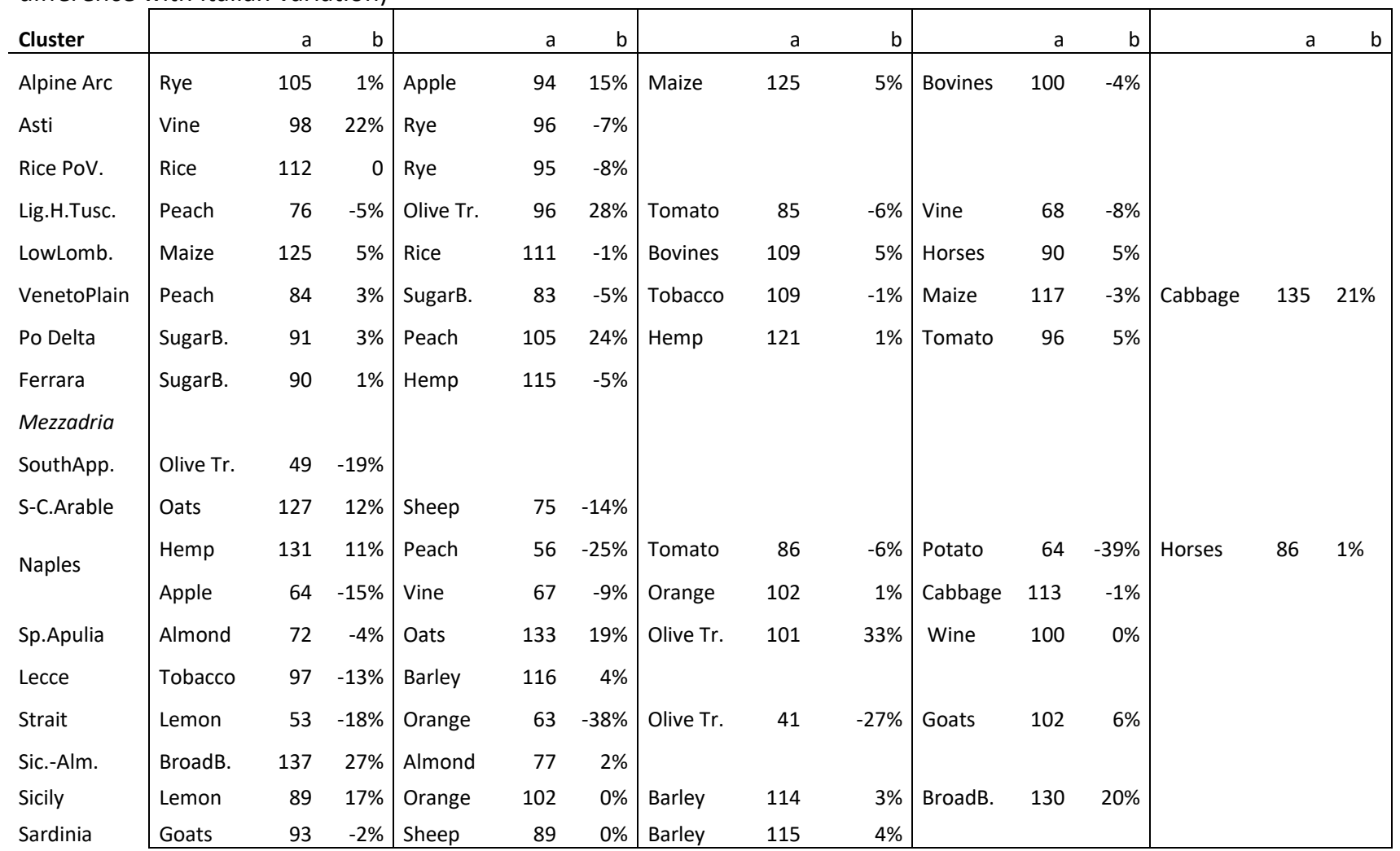

Source: Our Elaboration on Istat data (Cadastre 1929, ISTAT 1940)

Tab.6: Fertilizers and tractors

\begin{tabular}{|c|c|c|c|c|c|c|c|c|}
\hline \multirow[b]{3}{*}{ Clusters } & \multicolumn{6}{|c|}{ Fertilizers (kgs. of active component) per hectare } & \multirow{2}{*}{\multicolumn{2}{|c|}{$\begin{array}{c}\text { Tractors per } 1000 \\
\text { hectars of cultived area }\end{array}$}} \\
\hline & \multicolumn{3}{|c|}{ Phosphoric anhydride } & \multicolumn{3}{|c|}{ Nitrogen } & & \\
\hline & 1929 & 1936 & 1938 & 1929 & 1936 & 1938 & 1929 & 1936 \\
\hline Alpine Arc & 23,7 & 17,8 & 19,2 & 4,3 & 7,1 & 9,6 & 2,0 & 2,8 \\
\hline Asti & 12,6 & 8,8 & 12,8 & 3,2 & 4,3 & 8,1 & 1,0 & 1,5 \\
\hline Rice Po Valley & 35,4 & 34,6 & 36,2 & 22,3 & 25,7 & 30,5 & 2,5 & 4,1 \\
\hline Liguria-High Tuscany & 15,7 & 9,2 & 9,9 & 5,2 & 6,8 & 8,2 & 0,7 & 0,9 \\
\hline Low Lombardy & 31,6 & 33,5 & 35,7 & 9,8 & 15,4 & 21,6 & 4,4 & 6,4 \\
\hline Veneto Plain & 32,6 & 27,2 & 27,8 & 5,9 & 7,6 & 10,3 & 4,9 & 6,6 \\
\hline Po Delta & 28,9 & 34,3 & 35,8 & 3,5 & 6,5 & 11,2 & 5,3 & 7,5 \\
\hline Ferrara & 27,7 & 32,4 & 34,5 & 7,4 & 10,1 & 13,1 & 2,1 & 6,4 \\
\hline Mezzadria & 27,6 & 21,3 & 24,1 & 3,9 & 5,8 & 8,0 & 2,3 & 2,9 \\
\hline Southern Appennines & 6,7 & 7,6 & 9,2 & 1,6 & 2,6 & 3,2 & 0,4 & 0,7 \\
\hline Centre-South Arable & 5,4 & 6,0 & 7,9 & 0,8 & 1,2 & 2,0 & 1,2 & 1,7 \\
\hline Naples & 22,7 & 16,7 & 17,5 & 12,7 & 16,9 & 22,7 & 0,5 & 1,0 \\
\hline Spec. Apulia & 8,5 & 7,9 & 9,5 & 1,4 & 2,1 & 3,6 & 0,5 & 0,5 \\
\hline Lecce & 8,0 & 7,0 & 10,3 & 2,0 & 2,9 & 5,3 & 0,3 & 0,7 \\
\hline Messina Strait & 3,3 & 4,3 & 6,6 & 1,5 & 1,9 & 3,7 & 0,1 & 0,1 \\
\hline Sicily-Almonds & 17,4 & 18,7 & 20,0 & 1,4 & 1,8 & 4,0 & 0,4 & 0,5 \\
\hline Sicily & 8,0 & 8,0 & 10,3 & 1,8 & 1,9 & 3,6 & 0,3 & 0,4 \\
\hline Sardinia & 5,3 & 4,9 & 8,0 & 0,3 & 0,5 & 1,1 & 0,3 & 0,5 \\
\hline Italy & 17,3 & 15,2 & 17,1 & 3,7 & 5,3 & 7,4 & 1,5 & 2,1 \\
\hline
\end{tabular}

Source: Our Elaboration on Istat data (Bollettino, ISTAT 1940) 
Fig. 3: Italian Clusters

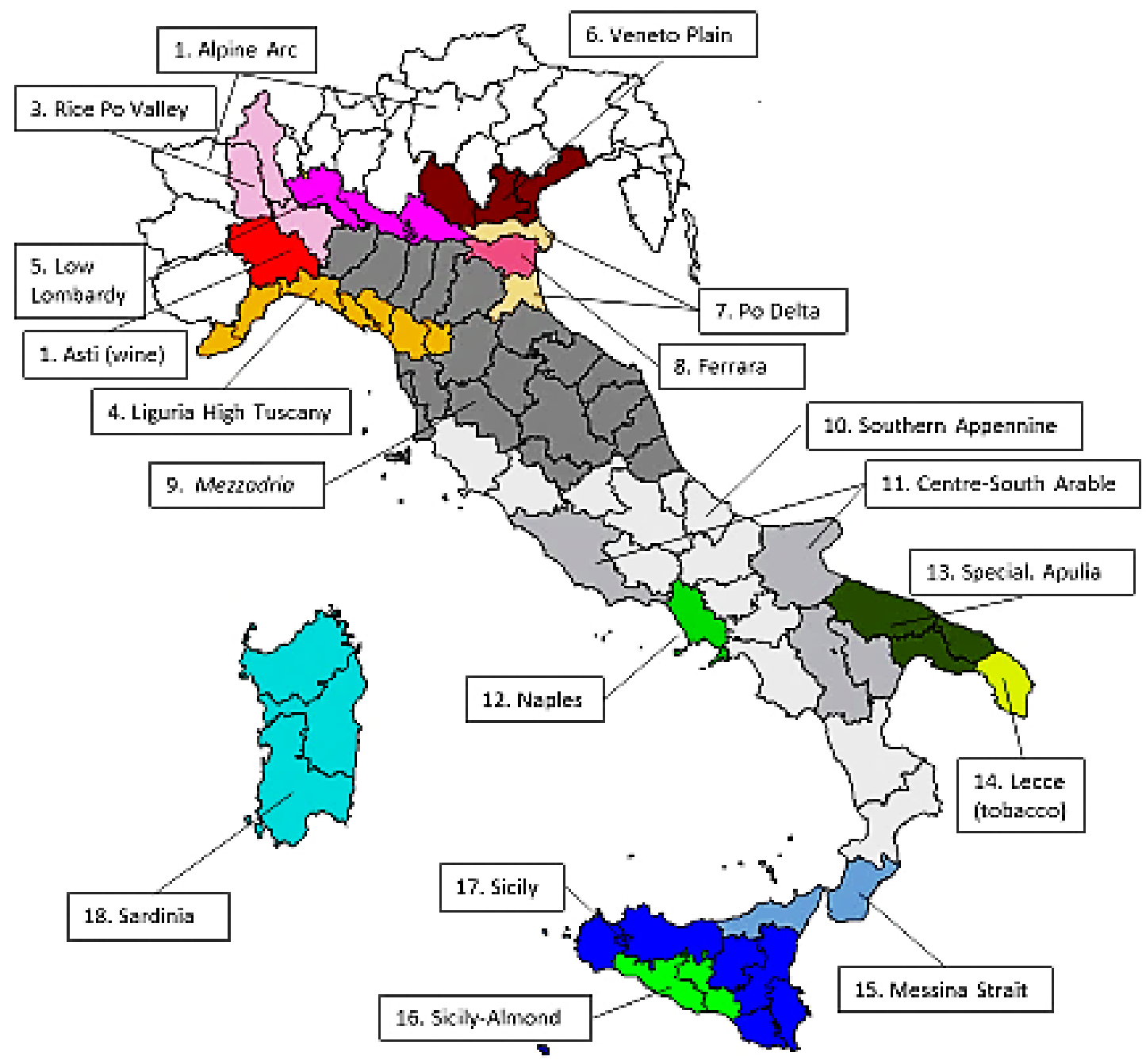




\section{Appendix 1 - The Clusters of Italian Agriculture in 1929}

The geography of Italian agriculture resulting from the multivariate analysis carried out in this work is largely consistent with the available literature. At the same time, however, it introduces some distinctive elements that can represent stimulating insights for reflection and qualitative analysis. The overall partitioning of the clusters, as well as single pieces of evidence, such as the continuity between Liguria and the Tuscan northern part of the Apennines, represent a specific picture of the rural areas of the peninsula in the interwar period based mainly on the product orientations of its agriculture.

Cluster 1 consists of twenty provinces in the Alpine region, in Northern Italy, characterized by a composite territory: besides mountains and valley floors it also includes dry plain portions of the Po Valley (similar to cluster 6 ) and the peculiar hillside setting of the Pre-Alps, characterized, for instance, by the silk economy, which was however already declining in the Twenties. Nonetheless, it is mainly a mountain agriculture (component C) with a large presence of woods $(30.5 \%$ of the Afa), permanent grasslands (68.5\% of the national total), and pastures. In this typical forestrypastoral economy, the scarce arable ${ }^{5}$ and woody crops are divided into numerous directly managed tiny farm units, essentially used for the food requirements of farming families and their small communities (Coppola 1989). Marketing concerns mainly pears and apples (39.5\% of Italian production), timber or animal foodstuffs, especially milk, linked to the widespread cattle breeding. Cluster 4 (seven provinces in Liguria and Upper Tuscany) is a sort of continuation of the previous cluster, with a prevailing mountain belt characterized by rugged terrains, rich in woods, pastures (component $\mathrm{C}$ ), and subsistence productions such as chestnuts (32\% of the national total), potatoes $(\mathrm{J})$, and a fragmented ownership with tiny plots. This barrier shelters the thin coastal strip of land at its feet, the Riviera. Here a climate mitigated by the sea allows the cultivation of flowers, palm trees and vines at altitudes sometimes exceeding 600 meters. In fact, strenuous and accurate terracing made it possible to transform arid cliffs into magnificent gardens (cabbages, tomatoes) and lush orchards, rich in olive groves and intensive fruit crops (E). The dichotomy between the poor agriculture of the hinterland and the intensive and rational production along the coast is also reflected in the human settlements, which are sparse inland and very dense on the coast.

The Po Valley includes three clusters. The first, Cluster 5, which includes the provinces of Milan, Cremona and Mantua, is characterized exclusively by component $A$. It is the typical intensive agriculture of Low Lombardy, the result of a centuries-old investment in canalizations and hydraulic arrangements that made it one of the richest rural areas in Europe. It relies on the interaction between (artificial) meadows, which benefit from the abundance of water, wheat and maize alternated with fodder, and a large livestock capital (cattle and pigs). The latter represents a means of production and a source of income, providing meat, milk for butter, cheese like Grana (Parmesan) and manure. It is based on a precocious capitalist agriculture with a few products, large tenancy with a significant use of farm laborers, and an integrated supply chain, which enhances a traditional production cycle connected with the dense market and industrial network of the Po Valley (Cafagna 1990).

\footnotetext{
${ }^{5}$ A typical Central European cultivation like rye stands out among the grains, constituting $56.7 \%$ of Italian production.
} 
Cluster 3 - the provinces of Vercelli, Novara and Pavia - is a variant of the previous one, characterized by intensive agriculture (component A) with a marked rice specialization (K). Although small-scale conduction is widespread, the large rice-growing farm is the economically dominant form, with its ample availability of capital and wage earners (fixed and seasonal).

Similar features are also partly shared by Cluster 6 , composed of three plain provinces in Veneto (also comparable with the lowland portions of several Alpine provinces). However, wheat, maize, meadows and bovines (component $A$ ) are associated here with industrial crops (F) such as sugar beet $(19.6 \%$ of the national production) or tobacco $(13.9 \%)$, and orchards $(\mathrm{J})$, that produce, for instance, $20.5 \%$ of Italian peaches. Moreover, unlike the more Western clusters, small-scale conduction is largely predominant. Nonetheless, soil fertility and a dynamic urban network promoted an intensive agriculture, diversified and relatively rich in capital.

Finally, three further clusters are located in Northern Italy. Cluster 2 coincides with the sole province of Asti, Piedmont. Its features are the hilly conformation and the marked presence of vines (even more extended than the wheat acreage), together with widespread "dry" permanent meadows and a connected high load of bovines (components $D$ and $E$ ). This intensive agriculture practices advanced farm combinations, and is characterized by a prevalent diffusion of small ownership, often specialized in high quality wine production (Barolo, Barbera, Vermouth, etc.).

The provinces of Rovigo and Ravenna belong to Cluster 7, whereas Ferrara, which is between the former, is part of Cluster 8 . These provinces are all located around the Po Delta and share similar features, in particular the prevalence of industrial crops (component F). Both clusters present large cultivations of sugar beet (Ravenna and Rovigo alone provide $38.1 \%$, Ferrara $16.6 \%$ of the national production), hemp (Ferrara totals $42.5 \%$ ), and to a lesser extent tomatoes, tobacco, etc. All these crops are strictly integrated with the relative industrial transformation sectors which, especially in the case of sugar, are large oligopolistic enterprises strongly protected by the State (Sabbatucci Severini 2004). In this intensive farming area, livestock is less important than in the rest of the Po Valley, the high yields of arable crops (mainly wheat and maize, component A) being guaranteed by the fertility of the recently reclaimed alluvial soil (Polesine) and the widespread use of machinery and fertilizers. This industrial agriculture, based on wage laborers and good capital endowment, subordinates rotations to the variation in crop prices, and is able to capture State support. In the case of Ferrara, this versatility also includes rice cultivations $(K)$ and peaches. Other kinds of orchards are of secondary importance here, while they are relevant in the Rovigo and Ravenna cluster (component J).

Cluster 9 includes eighteen provinces in Central Italy and is characterized by the absence of marked specializations and a multi-crop vocation (component E). It can be identified with the Mezzadria, the sharecropping form of conduction typical of the area, which in 1929 involved 2/3 of the employees in the primary sector of the Marche region. There is also a significant presence of small property here, especially on mountain slopes. Mezzadria is a traditional rural system that even in the 20th century continued to protect the hilly terrain of Central Italy from the run-off water (Anselmi 1990, Biagioli 2013). It implies the residence of farming families, with fields cultivated in order to satisfy the domestic consumption needs of the land-holder and to ensure an income (in kind) for the landowner. Sharecropping favors a wide variety of crops, a lack of productive specialization, high labor intensity with regular rotations and few technical innovations. 
It is characterized by small and medium-sized property, fragmentation of the farms, and a scarce capital accumulation, as well as an orientation to strictly local markets. Its low dynamism is compensated by high resilience, due to the flexibility of production factors and the ability to optimize the income sources of family-based conduction.

Southern Italy presents a more articulated situation, with nine clusters, six of which are specialized to different extents. In the first set, extensive cultivation prevails. In particular, Cluster 10 consists of twelve provinces in the mountainous and hilly land lying along the Southern Apennines which provide the basic productions of the area, such as durum wheat, olives, sheep herding, etc., with no particular specialization except potatoes (component J). This is related to a marginal agriculture with limited technical development, low yields and a polarization between large inefficient properties and scattered small ownership.

Simple arable land (component B) characterizes five further provinces in Cluster 11, which represent the typical Southern agriculture based on grains (wheat, oats) and pastures (1/5 of Italian sheep). The cluster encompasses morphologically different contexts such as the rugged Lucania, the Agro romano, the Tuscan Maremma or the Foggia plain, which are however characterized by a similar farm model connected with large estates with day laborers, low and erratic yields (from year to year), land which is often unhealthy and poor in urban settlements.

Cluster 18, Sardinia, shows similarities with the previous two. Generally speaking, it represents a scarcely cultivated region, with many vacant lots (component $\mathrm{C}$ ) due to the adverse climate, a malarial environment, and poor soil fertility. Its lands, partly mountainous and hilly, are used for the extensive cultivation of wheat (component B), and as woods and pasture to breed sheep and goats. Technical progress is hampered by the lack of workers, a very centralized settlement, insufficient capital and infrastructures, and a property structure divided between large estates and small units, both of which are inefficient. Land reclamation improved some local situations, without solving the issues of a generally backward and often archaic type of agriculture.

The other Southern clusters present higher specialization, although at different levels. A significant element is the presence of woody crops, that require larger and more long-term investments than the arable land (Bevilacqua 2000: 163-218).

Cluster 15 includes the provinces of Reggio Calabria and Messina, on the two sides of the Strait, where agriculture is strongly constrained by orography and climate. The roughness of the area (mountainous for about $2 / 3$ and devoid of plains) hinders the diffusion of arable crops. The steep local slopes are crowded with flocks of sheep and goats, whereas the mild climate of the coast favors woody crops such as vines, olive trees and especially citrus fruits (component G), grown profitably even in confined spaces. These features identify a production pattern similar in some respects to Liguria-Upper Tuscany, characterized by the dichotomy between mountain livelihoods, here linked to sheep, and the "rich", export-oriented woody productions of the coast.

Cluster 16 includes the provinces of Agrigento and Caltanissetta, in the middle of Sicily. It is an almost entirely rural area, with reduced livestock and a large incidence of extensively cultivated arable land (component B). Yields are higher than the rest of the island thanks to the quality of the soils and the massively practiced rotation between durum wheat and broad beans. Another significant element is the specialization in the almond crop (component $\mathrm{H}$ ), especially the most renowned varieties. Representing $0.5 \%$ of the Italian Afa, this area produces $15.6 \%$ of the broad 
beans and $31.5 \%$ of the national almonds. In this "Sicily-Almond" cluster, however, the limited water supply for irrigation hindered the spread of citrus fruits and other tree crops. The territory was largely malarial and the population was prevalently agglomerated. Employment was polarized between small direct conduction and paid work on large estates.

The six remaining Sicilian provinces belong to Cluster 17, that contains the typical features of Sicilian agriculture, which are partially present in both the Strait Cluster (which, however, lacks arable land) and the Sicily-Almond area (where citrus fruits are absent). Here, similar to the rest of the South, wheat is grown extensively with low yields (component B), forage is poorly developed (the primary cause of cattle poverty), ownership is polarized between small properties and large estates relying widely on day laborers. However, at the same time tree crops are widespread (component $\mathrm{G}$ ), above all vines, almonds and citrus orchards $(\mathrm{H})$, which produce about half of the Italian oranges and lemons.

Two further specialized clusters are located in Apulia, south of Foggia. Cluster 13 groups together the provinces of Bari, Brindisi and Taranto, characterized by extensive wheat farming (component B) but also specialized in woody crops (component D), which produce $6 \%$ of Italian wine, $15 \%$ of olive oil, and $34.6 \%$ of almonds. It is a rich, export-oriented agriculture based on significant capital investments, that however make it less flexible, because of the difficulty in reconverting decadeold vineyards and olive groves. In this specialized Apulia land ownership is split equally. Fruit trees require care and manual treatment, and therefore rely heavily on wage workers rather than on machinery.

Cluster 14 is the sole province of Lecce, and represents a variant of the previous group. Along with cereals (component B) and woody crops (D) the main specialization is tobacco, that here totalizes $29 \%$ of the national production and $38.5 \%$ of the dedicated terrain. Land ownership is very fractioned, with some incidence of sharecropping. Several wage earners are employed with different levels of productivity (high for tree crops, low for arable land) in the various laborintensive cultivations in the area.

Cluster 12 corresponds to the province of Naples, and presents a peculiar combination of specialization and diversification. Its agriculture includes poor (such as potatoes, component J) and "rich" cultivations, such as tomatoes ( $10 \%$ of the national output), subsistence and industrial crops (F) like hemp (ca. 1/4 of the national total), as well as productions typical of other environments, like rye (A), and those characteristic of the South, such as vines, citrus fruits ( $G$, above all oranges) and fruit (D). The favorable nature of the soil (often of volcanic origin) and the mild climate determine a wide biodiversity, that ensures risk diversification. The presence of a large port and an industrial town guarantees a plurality of outlets and is associated with a dynamic food industry producing tomato sauce, canned food, pasta, etc. Significantly, the pioneering study by Zattini (1924) puts Naples as the top Italian province for agricultural gross salable product per hectare. 
Literature (Page quotations from specific editions indicated in brackets)

Aldcroft, D.H., 1977. From Versailles to Wall Street 1919-1929, Berkeley: Ucla Press (Harmondsworths, 1978)

Agnoletti, M. (ed.), 2011. Paesaggi rurali storici. Per un catalogo nazionale, Roma-Bari: Laterza

Anselmi, S., 1990. 'Mezzadri e mezzadrie nell'Italia centrale', In Bevilacqua, vol. III, pp. 201-260.

Baffigi, 2013. 'I conti nazionali', in Toniolo, pp. 215-256.

Banfield, E.C., 1958. The Moral Basis of a Backward Society, Glencoe: The Free Press

Berle, A.A., Means, G.C., 1968. The Modern Corporation and Private Property, New York: Harcourt Brace \&World.

Bevilacqua, P., ed., 1989-1992. Storia dell'agricoltura italiana in età contemporanea, Venezia: Marsilio (3 vols.)

Bevilacqua, P., 1997. Breve storia dell'Italia meridionale dall'Ottocento a oggi, Roma: Donzelli.

Bevilacqua, P., 2000. Tra natura e storia. Ambiente, economia, risorse in Italia, Roma: Donzelli

Bevilacqua, P., 2016. 'La questione meridionale nell'analisi dei meridionalisti', in Cassese, pp.15-28

Bevilacqua, P., Rossi Doria, M. (Eds.), 1984. Le bonifiche in Italia dal '700 ad oggi, Roma-Bari: Laterza

Biagioli, G., 2013. 'Mezzadria, métayage, masoveria. Un contratto di colonia parziaria e le sue interpretazioni tra Italia, Francia e Catalogna', Proposte e ricerche, 71, pp. 5-29.

Bollettino mensile di statistica agraria e forestale, 1928 (I). Roma: Istat.

Bonelli, F., 1978. 'Il capitalismo italiano. Linee generali d'interpretazione', in Storia d'Italia. Annali 1, Dal feudalesimo al capitalismo, Torino: Einaudi, pp. 1193-1255.

Brianta, D., 1983. 'Risicoltura e fascismo negli anni della crisi. Alle origini dell'Ente nazionale risi 1927-1933', Agricoltura e forze sociali in Lombardia nella crisi degli anni trenta, Milano: FrancoAngeli, pp. 255-290

Broadberry, S.N., Giordano, C., Zollino, F., 2013. 'La produttività', in Toniolo, pp. 257-312.

Cadeddu, A, Lepre, S., Socrate, F., 1975. 'Ristagno e sviluppo nel settore agricolo italiano (19181939', Quaderni storici, 29-30, pp. 497-518

Cafagna, L., 1990. Dualismo e sviluppo nella storia d'Italia, Venezia: Marsilio.

Cassese, S. (Ed.), 2016. Lezioni sul meridionalismo, Bologna: II Mulino.

Ciccarelli, C., Fenoaltea S., 2010. 'Attraverso la lente d'ingrandimento: aspetti provinciali nella crescita industriale dell'Italia postunitaria', Quaderni di storia economica, 4, Roma: Banca D'Italia.

Ciocca, P., 2007. Ricchi per sempre?, Milano: Bollati Boringhieri. 
Cohen, J., 1976. 'Rapporti agricoltura-industria e sviluppo agricolo', in P. Ciocca, G. Toniolo (Eds.), L'economia italiana del periodo fascista, Bologna: II Mulino, pp. 379-408.

Cohen, J., 1979. 'Fascism and Agriculture in Italy: Policies and Consequences', Economic History Review, 32.1.

Cohen, J., Federico, G., 2001. Lo sviluppo economico italiano 1820-1960, Bologna: Il Mulino

Coppola, G., 1989, 'La montagna alpina', in Bevilacqua 1997-2002, 1, pp. 495-531.

Corona, G., Masullo, G. 1989. 'La terra e le tecniche' , in Bevilacqua 1997-2002, 1, pp. 353-450.

Crainz, G., 1989, 'La cascina padana', in Bevilacqua 1898-1991, 1, pp. 37-76

Daniele, V., Malanima, P., 2011. Il divario Nord-Sud in Italia 1861-2011, Soveria Mannelli: Rubettino

De Bernardi, A., D'Attorre, P.P. (eds.), 1996. Studi sull'agricoltura italiana, Milano: Feltrinelli

Delli Gatti, D., Gallegati, M., Greenwald, B.C., Russo, A., Stiglitz, J.S, 2012. 'Mobility constraints, productivity trends, and extended crises', Journal of Economic Behavior \& Organization, 83.3.

Eichengreen, B., 1992. Golden Fetters, Oxford: UP

Esposti, R., 2014. 'On Why and How Agriculture Declines. Evidence from the Italian Post-WWII Experience', Structural Change and Economic Dynamics, 31.

Fano, E., 1975. 'Problemi e vicende dell'agricoltura italiana tra le due guerre', Quaderni storici, 29-30, pp. 468-496.

Federico, G. 2005, 'Not Guilty? Agriculture in the 1920s and the Great Depression', The Journal of Economic History, 65.4.

Federico, G., Natoli, S., Tattara, G., Vasta, M., 2011. I/ commercio estero italiano 1862-1950, RomaBari: Laterza

Felice, E., 2007. Divari regionali e intervento pubblico, Bologna: II Mulino

Felice, E., 2014. Perché il Sud è rimasto indietro, Bologna: II Mulino

Fenoaltea, S., 2006. L'economia italiana dall'Unità alla Grande guerra, Roma-Bari: Laterza

Fortunato, G., 1911. II Mezzogiorno e lo Stato Italiano, Roma-Bari: Laterza

Friedman, M., Schwarz, H.J., 1963. A Monetary History of the Unites States, Princeton: UP

Galbraith, J.K., 1955. The Great Crash, 1929, Boston: HMHC

Gambi, L., 1972.'I valori storici dei quadri ambientali', Romano, R., Vivanti, C. (eds), Storia d'Italia Einaudi, I, I caratteri originali, Torino: Einaudi, pp. 3-132.

Gambi, L. 2008. La costruzione dei piani paesistici. Scritti di Lucio Gambi sull'Emilia Romagna e dintorni. Bologna: UP.

Gerschenkron, A., 1962. Economic Backwardness in Historical Perspective, Cambridge (Mass.): Harvard UP. 
Giusti, U., 1943. Caratteristiche ambientali italiane agrarie, sociali, demografiche 1815-1942. Roma: Failli

Gramsci, A., 1949. Il Risorgimento, Roma: Editori Riuniti (1973)

Hansen, H., 1939. 'Economic Progress and Declining Population Growth', American Economic Review, 29.

Inea, 1938. Lo spopolamento montano in Italia. Relazione generale, Roma: Failli

Inea, 1954. Annuario dell'agricoltura italiana, Vol. VII. Roma: Panetto \& Petrelli

Istat, 1934. Censimento del bestiame, Roma: Failli.

Istat, 1940. Annuario statistico dell'agricoltura italiana 1936-1938, Roma: Failli

Jacini, S., 1881. Atti della Giunta per la inchiesta agraria e sulle condizioni della classe agricola, Roma: Forzani

Jolliffe, I.T., 2002. Principal component analysis, New York: Springer.

Kindleberger, P.C., 1973. The World in Depression, 1929-1939, Berkeley: Ucla (Milan 1988)

Lupo, S., 1990. Il giardino degli aranci, Venezia: Marsilio.

Martinelli, P., 2014. 'Von Thünen South of the Alps: Access to Markets and Interwar Italian Agriculture', European Review of Economic History, 18.

Mastrolia, F. A., 2008. 'La coltivazione e la lavorazione del tabacco in Terra d'Otranto tra Otto e Novecento', Proposte e Ricerche, 61.

Minsky, H.P., 1982. Can "It" Happen Again?, Armonk: Sharpe

Nenci, G., 1997. Le campagne italiane in età contemporanea, Bologna: Il Mulino

Niccoli, V., 1898 and $1927^{2}$. Economia rurale, estimo e computisteria agraria, Torino: Utet

Nitti, F.S., 1900. Nord e Sud, Torino-Roma: Roux e Viarengo.

Nützenadel, A., 2001, 'Economic Crisis and Agriculture in fascist Italy, 1927-1935. Some New Considerations', Rivista di storia economica, XVII.3.

Ohlin, B., 1931. The Cause and Phases of the World Economic Depression, Geneva: League of Nations

Orlando 1974

Orlando, G. 1984. Storia della politica agraria in Italia dal 1848 a oggi, Bari: Laterza.

Patnaik, U., 2003. 'Global Capitalism, Deflation and Agrarian Crisis in Developing Countries', Journal of Agrarian Changes, 3.1/2, pp. 33-66.

Putnam, R.D., 1993. Making Democracy Work. Civic Traditions in Modern Italy, Princeton: UP

Rizzi, P.L., Pierani, P., 2006. Agrefit. Ricavi, costi e produttività dei fattori nell'agricoltura delle regioni italiane (1951-2002), Milano: FrancAngeli. 
Romeo, R., 1959. Risorgimento e capitalismo, Roma-Bari: Laterza

Rossi Doria, M., 1953 'La struttura e i problemi fondamentali dell'agricoltura meridionale', in Cassa per il mezzogiorno (ed.), Problemi dell'agricoltura meridionale, Napoli: Istituto Editoriale per il Mezzogiorno (pp. 135-154)

Sabbatucci Severini, P., 2004. Il capitalismo organizzato. Venezia: Marsilio

Sereni, E., 1961. Storia del paesaggio agrario italiano, Roma-Bari: Laterza.

Sereni, E., 1968. Il capitalismo nelle campagne (1860-1900), Torino: Einaudi

Soresina, M., 2001. Conoscere per amministrare, Milano: FrancoAngeli.

Stampacchia, M., 2000. Ruralizzare I'Italia!, Milano: FrancoAngeli

Storia d'Italia. Le regioni dall'Unità ad oggi, 1997-2002. Torino: Einaudi

Svimez, 2011. 150 anni di statistiche italiane: Nord e Sud 1861-2011, Bologna: II Mulino

Sweezy. P.M, 1968. The Theory of Capitalist Development, New York: Monthly Review Press

Tassinari, G., 1941. Manuale dell'agronomo. Roma: Reda

Tattara, G., 1978, 'La battaglia del grano', in Toniolo, G. (ed.), L'economia italiana 1861-1940, Roma-Bari: Laterza, pp. 337-380.

Timoshenko, V., 1933. World Agriculture and the Depression, Ann Arbor: Michigan UP

Tino, P., 1997. Campania Felice? Territorio e agricoltura prima della "grande trasformazione. Roma: Donzelli.

Tino, P., 2016. 'Il rapporto tra agricoltura e allevamento nel Mezzogiorno del Novecento', Mélanges de l'Ecole Française de Rome, 128.2

Toniolo, G. (ed.), 2013. L'Italia e l'economia mondiale dall'Unità ad oggi, Venezia: Marsilio

Zamagni, V., 1993. Dalla periferia al centro. La seconda rinascita economica dell'Italia 1861-1990, Bologna: II Mulino

Zattini, G., 1924. 'Valutazione della produzione lorda dell'agricoltura italiana', Notizie periodiche di statistica agraria, 15.4. 